\title{
TEMPO MÍNIMO DE PROPAGANDA ELEITORAL EM RÁDIO E TV: POR UM JOGO JUSTO ${ }^{1}$
}

\author{
Minimum Broadcast Time on Radio and Television in Elections
}

\begin{abstract}
Resumo: A distribuição do tempo de propaganda eleitoral em rede de rádio e televisão obedece a critérios de proporcionalidade entre os partidos, de acordo com a quantidade de parlamentares no Congresso Nacional. O problema não está na proporcionalidade, que é parâmetro validamente adotado pelo legislador, mas na falta de um piso. O tempo mínimo de propaganda é relevante porque pode representar uma afronta direta ao que seria razoável. A exposição ínfima equivale à falta de exposição, pela impossibilidade de transmissão eficaz de uma ideia. A propaganda nessa condição será uma não-propaganda. O cerceamento da propaganda eleitoral não é uma violação ao direito do candidato apenas mas, muito além, constitui supressão do direito do eleitor de ser informado, de conhecer os players e suas ideias. Por isso a garantia do direito de propaganda deve ser um norte para a questão, por compor a base do equilíbrio do pleito. A igualdade formal há de ceder à proporcionalidade definida pelo legislador, mas não pode suprimir por completo as condições mínimas, porque estaria a afetar negativamente a legitimidade do processo eleitoral. A questão se põe então em torno de encontrar o limite do razoável, o tempo mínimo a ser garantido a qualquer candidato. E esse critério pode ser encontrado no instituto do direito de resposta, que tem base constitucional e vem regulado pela lei como um mecanismo de reparo a manifestações indevidas. Pois a lei define que o direito de resposta será exercido de forma proporcional à ofensa, mas estabelece um piso, um tempo mínimo, que é de um minuto, a ser garantido ainda que a ofensa tenha sido em prazo inferior. A mens legis aqui teve por premissa considerar que em menos de um minuto não é possível razoavelmente transmitir uma mensagem, uma ideia. E essa é uma referência importante, dentro do mesmo subsistema legal eleitoral, orientada pelos mesmos princípios e calcada na mesma garantia do direito de informação, de modo que pode ser perfeitamente adotada. Em conclusão, o limite mínimo para o tempo de propaganda eleitoral pode ser empregado como forma de garantia dos
\end{abstract}

\section{Nelson Zunino Neto}

princípios referidos e em decorrência de uma interpretação conforme a Constituição Federal.

Palavras-chave: Propaganda eleitoral. Direito de informação. Legitimidade da eleição. Igualdade. Proporcionalidade.

Abstract: The distribution of broadcast time on radio and television networks during Brazilian elections follows the criteria of proportionality among the parties, according to the number of parliamentarians represented in the Chamber of Deputies. Proportionality is not the problem; it is a valid parameter adopted by the legislator. The problem is the absence of a minimum time. The right minimum air time is relevant because it can guarantee reasonable fairness. Too little exposure is equivalent to no exposure since ideas cannot be effectively transmitted. Restriction of electoral advertising is a violation of the candidate's right and a suppression of the voter's right to be informed, to know the political players and their ideas. Therefore, the guarantee of the right to advertise during elections must guide the debate on the minimum air time to balance campaigns. Formal equality must privilege the proportionality defined by the legislator. However, this equality should not completely remove the minimum conditions to compete because it would be negatively affecting the legitimacy of the electoral process. Thus, it is crucial to find a reasonable minimum air time for all candidates. This study argues that this issue could use the same criterion adopted in the rule applied to the right of reply, which has a constitutional basis in Brazil and is considered by law as a mechanism to repair undue manifestations. The legislation on the right of reply establishes the air time in proportion to the offense, with a minimum of one minute, which is guaranteed even if the offense took less time. The premise of the mens legis was to consider that in less than a minute, it is not possible to transmit a message properly. Keywords: Electoral propaganda. Right to Information. Legitimacy of the Election. Equality. Proportionality.

${ }^{1}$ Artigo baseado na obra Tempo Mínimo de Propaganda Eleitoral em Rádio e TV: por um jogo justo, Ed. Habitus, 2020, do mesmo autor.

Artigo recebido em 4 mar. 2020 e aprovado em 15 out. 2020. 


\section{Introdução}

Neste artigo, o que se pretende é abordar um ponto muito específico da propaganda eleitoral em rede de rádio e televisão, que é a necessidade de estabelecimento de um tempo mínimo destinado a qualquer candidato a cargo pelo sistema majoritário.

Nas eleições de 2018, dez dos treze candidatos à presidência tiveram menos de um minuto de tempo de propaganda eleitoral em rede. Isso não impediu que um deles, com apenas 8 segundos, fosse eleito com expressiva votação. Mas o que se discute não é a eficiência do veículo de comunicação, nem a importância dele para a campanha, e sim o fato de que todos os candidatos devem ter um espaço mínimo razoável para que suas ideias sejam conhecidas, seja porque se trata da liberdade de expressão destes, seja porque, principalmente, se cuida de garantir ao eleitorado o direito à informação.

A distribuição do tempo de propaganda eleitoral em rede de rádio e televisão obedece a critérios de proporcionalidade entre os partidos, de acordo com a quantidade de parlamentares no Congresso Nacional. O problema não está na proporcionalidade, que é parâmetro validamente adotado pelo legislador, mas na falta de um piso. O tempo mínimo de propaganda é relevante porque pode representar uma afronta direta ao que seria razoável. A exposição ínfima equivale à falta de exposição, pela impossibilidade de transmissão eficaz de uma ideia. A propaganda nessa condição será uma não-propaganda.

O cerceamento da propaganda eleitoral não é apenas uma violação ao direito do candidato, mas vai além: representa a supressão do direito do eleitor de ser informado, de conhecer os players e suas ideias. Por isso a garantia do direito de propaganda deve ser um norte para a questão, por compor a base do equilíbrio do pleito. A igualdade formal há de ceder à proporcionalidade definida pelo legislador, mas não pode suprimir por completo as condições mínimas, porque estaria a afetar negativamente a legitimidade do processo eleitoral.

As eleições de 2018 demonstraram claramente o grau de importância da propaganda eleitoral como um todo, e em especial o quanto o eleitorado precisa de informação. Com tempo ínfimo de propaganda em rádio e televisão um candidato foi presidente eleito com votação extraordinária e consigo levou o partido, que até então era inexpressivo, à condição de segundo maior do país em quantidade de parlamentares. 
Tudo isso se deu numa onda popular de proporções gigantescas, ao mesmo tempo em que esse mesmo eleitorado sequer teve a chance de ver e ouvir a mensagem desse candidato na propaganda de rádio e TV. Com tempo de 8 segundos, nada foi efetivamente apresentado, e com isso não se pode dizer que alguma informação, mínima que fosse, tenha sido oportunizada ao eleitor. E é preciso evitar o contra-argumento de que o próprio eleitor do candidato não precisa da propaganda dele. Primeiro, porque a decisão do voto - segundo pesquisas - se dá cada vez mais tarde, mais próxima ao dia da eleição. Segundo, porque a informação é um elemento que qualifica a decisão do eleitor, de modo que a ele deve ser garantido o direito de recebê-la.

Não se pode ignorar esse contexto, tanto quanto não se pode desconsiderar que os mecanismos de propaganda do sistema eleitoral devem se sujeitar à finalidade das regras eleitorais, que é conduzir a escolha dos representantes do povo de uma forma verdadeiramente democrática e legítima. Sem garantia do direito à informação ao eleitor, o processo não estará completo, e não traduzirá honestamente a expressão da soberania popular.

A questão se põe então em torno de perceber o limite do razoável, o tempo mínimo a ser garantido a qualquer candidato. E esse critério pode ser encontrado no instituto do direito de resposta, que tem base constitucional e vem regulado pela lei como um mecanismo de reparo a manifestações indevidas. Pois a lei define que o direito de resposta será exercido de forma proporcional à ofensa, mas estabelece um piso, isto é, um tempo mínimo, que é de um minuto, a ser garantido ainda que a ofensa tenha sido em prazo inferior.

A mens legis aqui teve por premissa considerar que em menos de um minuto não é possível, de forma razoável, transmitir uma mensagem, uma ideia. E esta é uma referência importante, dentro do mesmo subsistema legal eleitoral, orientada pelos mesmos princípios e calcada na mesma garantia do direito de informação, de modo que pode ser perfeitamente adotada.

Em conclusão, o limite mínimo para o tempo de propaganda eleitoral pode ser empregado como forma de garantia dos princípios referidos e em decorrência de uma interpretação conforme a Constituição Federal.

\section{O alicerce principiológico}

Não se trata de preciosismo. A base de um estudo desta natureza há de ser principiológica. Seja como informadores do direito ou parâmetros 
de interpretação, os princípios nos guiam pelas vias orgânicas, sistematizadas e hierárquicas dessa pirâmide jurídica a que nos submetemos a partir da Constituição Federal.

O alicerce, nesse caso, vem da Carta Magna e do sistema eleitoral. Elegemos nove princípios para nortear este ensaio. Os cinco primeiros são constitucionais, dois deles dentre os fundamentais: regime democrático e forma republicana, e três gerais: igualdade, proporcionalidade e razoabilidade. Os outros quatro são o sistema partidário, o equilíbrio no pleito, a paridade na competição e a legitimidade eleitoral. Não tem como fazer o bolo sem esses ingredientes.

\subsection{Democracia}

A democracia não está meramente na adoção do sufrágio universal, longe disso. Há quem defenda, aliás, que o voto muitas vezes tem efeito contrário - mas esse é assunto para outra oportunidade. No momento, cuida-se de verificar alguns elementos essenciais, além do voto secreto e universal, tais como a liberdade de expressão e a capacidade de compreensão, a amplitude da elegibilidade, a existência de imprensa livre, e a idoneidade do processo eleitoral. Quando um eleitor cultural ou politicamente alienado, ou desinformado, ou coagido por relações econômicas, dá seu voto, nem sempre estará contribuindo para o processo democrático, como expressão da soberania popular; eventual manipulação há de ser considerada e, obviamente, isso não traduz democracia.

\subsection{República}

O princípio republicano diz com a forma de governo, ou seja, o modus de sua instituição e a relação de poder entre governantes e governados. A coisa pública (res publicae, no latim) é um conceito necessário para a compreensão do republicanismo. A forma republicana de governo não deve ser tida como mero contraste à monarquia, mas como um indicativo de que o sistema precisa estar protegido diante de eventuais tentativas de assalto indireto ao poder, pela supressão da escolha popular ou da periodicidade dos mandatos. Sem uma República erigida nos moldes fixados, o próprio Estado estará sustentado por poderes deslegitimados, e portanto, suas ações - aí incluso o processo eleitoral derivado - estarão evidentemente comprometidas. 


\subsection{Igualdade}

A clássica definição de Aristóteles diz que se deve tratar igualmente os iguais e desigualmente os desiguais. A noção de igualdade como valor humano é tão antiga quanto a humanidade, de modo que a Bíblia contém diversas passagens com expressa referência. A igualdade aqui, por certo, se dá com referência a seres humanos, no contexto social, porque é no seio de uma sociedade ou de uma civilização que se pode compreender e avaliar os aspectos de uma relação igualitária ou não. Trata-se não da igualdade em si, que é a equivalência, mas de um princípio de igualdade, que é o tratamento a ser dispensado em determinadas circunstâncias. O processo eleitoral idôneo depende de uma tríplice igualdade: entre candidatos, entre eleitores, e como produto das regras do jogo.

\subsection{Proporcionalidade}

A proporcionalidade a que se refere a doutrina, em geral, acaba sendo muito mais um instrumento, um mecanismo, um modo para que se possa, por meio deste princípio, dosar os demais. Há também a conceituação que toma a proporcionalidade como princípio em si. A proporcionalidade como princípio autossuficiente é, comumente, dividida em três subprincípios: adequação, necessidade e proporcionalidade em sentido estrito. Essa classificação tem origem na doutrina alemã e é a mais difundida. Longe de se afastarem, contudo, essas acepções se complementam. No contexto de um processo eleitoral, consideradas as suas vicissitudes, a proporcionalidade será indispensável para que não se permita que a relação entre candidatos e eleitores se afaste do conjunto de normas e princípios que o sustentam.

\subsection{Razoabilidade}

$\mathrm{Na}$ pesquisa doutrinária é muito comum encontrar quem defina a razoabilidade como um princípio equivalente ao da proporcionalidade. Enquanto princípio constitucional, fecha o conjunto de arrimos para a compreensão do direito eleitoral na parte que diz respeito ao objeto deste breve estudo. Mas não se trata de um fecho qualquer. Inviável cogitar da interpretação das normas de direito eleitoral, especialmente para considerar a plenitude de um processo eleitoral que se possa chamar de legítimo, sem a presença da razoabilidade. Não é princípio de aplicação assertiva, como se pode considerar o republicanismo ou a democracia, nem ambivalente como 
a igualdade ou a proporcionalidade, mas de base mais negativa, já que, se é difícil identificar com precisão o que é razoável, muito mais acessível é a definição do que se mostra irrazoável. E não resistirá a mais singela apreciação judicial ou administrativa qualquer ato incorporado ao processo eleitoral que se revele evidentemente fora dos limites do aceitável.

\subsection{Partidarismo}

A chave do sistema partidário e sua ligação com o presente estudo, no que interessa, está na obrigatoriedade de filiação partidária para que uma candidatura possa se efetivar. É a dicção do art. 14, \3ㅜㅡ, V, da Carta Magna, que trata das condições de elegibilidade. O sistema importa aqui apenas em razão de que o tempo de propaganda é distribuído de acordo com a participação partidária no parlamento, e a conquista do mandato é um monopólio dos partidos. A conquista e não o exercício, já que há hipóteses válidas de desfiliação sem perda do mandato. $\mathrm{O}$ sistema partidário vincula candidatura e filiação. Essa inquestionável ligação revela que o legislador fez sobrepor a expressão dos partidos sobre o equilíbrio na transmissão de informações ao eleitor. A lei privilegiou o compromisso com as forças partidárias, em detrimento da mantença de uma isonomia nas condições da propaganda eleitoral. A dosagem não levou em conta eventuais extremos e o risco de que a escassez de tempo de algum candidato pudesse representar cerceamento no direito de informação e, por extensão, uma violação à legitimidade do pleito.

\subsection{Equilíbrio no pleito}

O equilíbrio eleitoral é um status de não desconformidade. Compreendem-se aqui todas as formas de violação da norma ou dos princípios, abrangendo mas não se limitando à paridade e à liberdade, e indo além. O equilíbrio eleitoral será, assim, o estado do pleito livre de máculas, no mais amplo sentido, consideradas ocorrências relevantes do ponto de vista jurídico com potencialidade para afastar qualquer dos elementos necessários à legitimidade das eleições e que, concomitantemente, represente ou possa representar vantagem ou desvantagem a um dos concorrentes. Nesse contexto, e para os fins deste estudo, a carência de informação ao eleitorado será certamente um relevante componente de desequilíbrio. 


\subsection{Paridade na competição eleitoral}

Derivada do princípio da igualdade, a paridade na competição eleitoral diz respeito à equivalência de condições entre os candidatos a um mesmo cargo em determinado pleito. Igualdade diz respeito ao mesmo estado (dade/tate), enquanto isonomia indica sujeição à mesma regra (nomia/nomo). Pode-se concluir, destarte, que diversamente do princípio da igualdade, em que o tratamento das pessoas será em função do seu estado de igualdade ou desigualdade em relação às outras, na isonomia o que se considera é a sujeição dessas à lei, que será indistinta, seja qual for a condição. Não se pode dizer, por isso, apenas igualdade, mas igualdade na competição, conceito mais consentâneo à noção de isonomia. Para evitar confusão de termos, contudo, prefere-se aqui a expressão "paridade na competição eleitoral", tomando-se então o sentido de que os competidores devem estar sujeitos às mesmas condições.

\subsection{Legitimidade}

Não basta que o processo seja fiel ao cumprimento da lei; isso já se contém no princípio da legalidade. Aqui impende mais que seguir a regra, mas atingir seu escopo, muito menos verificando os vícios no certame e muito mais garantindo condições para que o eleitor tenha possibilidade de fazer escolhas conscientes. Os inúmeros ataques a que está sujeito o livre exercício do voto são, induvidosamente, relevantes e merecedores da maior atenção pelo legislador, especialmente quando se trata de abusos, fraudes, atos de corrupção. Mas a par dessas condutas danosas, negativas, há outro contexto a ser observado e que aqui ganha enfoque especial, em face do objeto do presente estudo. Trata-se das condições do eleitor no seu mister. Sem liberdade não haverá voto legítimo. Sem consciência não haverá voto legítimo. Sem transparência no jogo não haverá voto legítimo. Sem igualdade não haverá voto legítimo. E sem informação não haverá liberdade, consciência, transparência ou igualdade. Esse ambiente é o que se persegue, e aí residirá, no mínimo, uma perspectiva de legitimidade do processo eleitoral.

\section{Propaganda eleitoral como direito à informação}

\subsection{Propaganda}

A expressão "propaganda" veio emprestada de uma técnica agrícola, a "mergulhia", que consiste na reprodução vegetal resultante do enterramento de um ramo de planta, para constituição, depois do enraizamento, 
de novo exemplar, a ser separado da original (FERREIRA, p. 1122), também chamada de propagação vegetativa. Mergulhia, em latim, é propagatio (QUEIROZ, 1959, p. 308), que por sua vez é "propagação" em português (op. cit., p. 282). Pelas mãos da Igreja Católica esse termo ganhou o emprego que tem hoje no conceito contemporâneo de difusão de ideias (FERREIRA, 1986, p. 1403).

De Patrícia Rosenzweig (2014) colhe-se que o Papa Gregório XV usou a expressão com tal sentido ao criar a Congregação della Propaganda Fide (propagação da fé) pelo Vaticano no século XVII, congregação esta que tinha como finalidade levar a fé cristã a todo o mundo conhecido. Desde 1967, esse órgão da Cúria romana se chama Congregação para a Evangelização dos Povos (TOMÁS, 2007), mas o termo propaganda permanece vivo até hoje.

É inevitável a comparação entre publicidade e propaganda. Há autores que consideram os termos como sinônimos. O termo "publicidade" vem do latim publicus, que deriva de uma forma do latim medieval, poplicus, relativo a populus, que significa povo.

Para alguns autores, a publicidade está mais ligada à divulgação comercial, enquanto a propaganda à difusão ideológica (BENJAMIN, 2010; SERRANO, 2013 e GOMES, 1997). Todavia, não nos anima considerar a vocação comercial da publicidade para distingui-la da propaganda, porque embora seja uma característica válida, não é essencial, já que uma ideia - e assim a candidatura - pode estar envolvida num contexto de objetificação, exatamente como produto consumível.

Diante dessas incoincidências e imprecisões terminológicas, é mais adequado manter o foco no aspecto de que a publicidade tem o fim de tornar algo público, porque este sempre foi o sentido do termo, desde a origem nas primeiras civilizações. A propaganda, por sua vez, tem por missão o ato de convencer, e desde que a expressão deixou o reduto agrícola para ser empregada no meio eclesiástico foi com a acepção de interferir na vontade humana em defesa de causas, como fez a Cúria.

Trazendo para o sentido jurídico, pode-se então considerar propaganda como a divulgação com fim persuasivo, e a publicidade como o ato de tornar algo público, independentemente de convencimento.

A propaganda (e a publicidade comercial) no Brasil tem basicamente quatro fontes principais de regulação, e outras secundárias. A Lei 
4.680, de 18 de junho de 1965, que "dispõe sobre o exercício da profissão de publicitário e de agenciador de propaganda", diz no art. 17: "A atividade publicitária nacional será regida pelos princípios e normas do Código de Ética dos Profissionais da Propaganda, instituído pelo I Congresso Brasileiro de Propaganda, realizado em outubro de 1957, na cidade do Rio de Janeiro.”

Esse código foi revisado em 2014 pela Associação dos Profissionais de Propaganda, em São Paulo, e serve como um "documento orientador do comportamento ético-profissional a ser seguido por quem atua com publicidade em agências, veículos e anunciantes" (ASSOCIAÇÃO, 2014). A referida lei foi regulamentada pelo Decreto 57.690, de $1^{\circ}$ de fevereiro de 1966, cuja última alteração foi em 2002 e fez expressa referência às "Normas-Padrão da Atividade Publicitária, editadas pelo Conselho Executivo das Normas-Padrão - CENP”. Esse Conselho é um organismo privado, constituído por associações ligadas a empresas de propaganda, de comunicação, emissoras de rádio e televisão e congêneres.

Finalmente, existe o Conselho Nacional de Autorregulamentação Publicitária - CONAR, entidade privada que congrega associações nacionais de anunciantes, agências, emissoras de rádio e televisão, jornais e outros veículos. Com a finalidade de fiscalizar e normatizar a propaganda comercial, o CONAR editou o Código Nacional de Autorregulamentação Publicitária (o termo deveria ser "autorregulação"), de aplicação no âmbito privado (embora faça referência à publicidade governamental) e sujeição voluntária.

A propaganda ganhou também uma atenção especial no Código do Consumidor (Lei 8.078, de 11 de setembro de 1990), além de menções na legislação esparsa, como o caso da regulamentação da ANVISA sobre propaganda de medicamentos, dentre outras. Esse misto de normas públicas e privadas compõe o que Candido Almeida (2013, p. 13) chama de "modelo misto de regulamentação da publicidade".

Não há qualquer ingerência da legislação e dessas normas privadas sobre a propaganda eleitoral, cujo subsistema é autônomo - a propósito, o Código do CONAR diz no art. 11: "a propaganda política e a político-partidária não são capituladas neste Código.” Uma única referência indireta ao campo eleitoral está nas normas complementares do Código de Ética dos Profissionais da Propaganda, já referido, quando trata do uso inapropriado de pesquisas, "especialmente no campo político".

De todo modo essa regulamentação não repercute diretamente na seara eleitoral, a não ser para, no âmbito da hermenêutica, contribuir para 
a compreensão do sentido e dos limites da propaganda como mecanismo social. Vê-se desde logo a preocupação com o estabelecimento de regras, muitas vezes rigorosas, em contraposição à liberdade da iniciativa privada, o que revela justamente a necessidade de conter abusos, por conta da real influência da propaganda na vida das pessoas.

Essa influência é que será adiante abordada, para compor uma base importante no presente estudo: a propaganda é um elemento fundamental do processo eleitoral, com potencial para afetar a legitimidade da eleição e a própria democracia, de modo que não é possível ignorar, desconsiderar, relativizar ou minimizar a sua relevância e seus efeitos, razão pela qual o tempo mínimo é fruto direto dessa preocupação.

\subsection{Propaganda eleitoral}

\subsubsection{Taxonomia}

A propaganda eleitoral é espécie do gênero propaganda política. Usamos aqui a classificação tradicional, que subdivide a propaganda política em eleitoral, partidária, intrapartidária e institucional.

\subsubsection{Propaganda política}

Para Roberto Macedo (2007), “a propaganda política pode ser compreendida como uma definição ampla da fusão da propaganda ideológica com a propaganda eleitoral, sendo que na ideológica é a propaganda de ideias de cunho político realizado por qualquer indivíduo da sociedade, inclusive agremiações partidárias, desde que sem objetivos específicos de benefício de candidatos em pleitos eleitorais.” Jairo Gomes (op. cit., p. 465) acrescenta que a finalidade dessa é a obtenção ou manutenção do poder estatal. Djalma Pinto (2008, p. 241) afirma que ela é "voltada para a polis, aí compreendendo tudo o que se refere à cidade, ao Estado, ao modo de governá-lo”.

O termo "política" diz respeito à polis, cujo sentido é o de cidade, mas também estado ou comunidade, o que podemos englobar na expressão coletividade. A partir do conceito de que político (do grego politikés) é aquele que participa da vida da cidade, e considerando a visão aristotélica de que ela visa o bem comum, ou, na linha de Platão, à justiça, pode-se chegar à noção de que política é o esforço coletivo para tornar a vida mais justa. Traduzida essa ideia para o mundo jurídico, vamos buscar em Dalmo de Abreu Dallari (1993, p. 41) a observação de que a sociedade política visa "integrar todas as atividades sociais que ocorrem em seu âmbito”. 
Na fala de Hermann Heller (1947, p. 188), “o objeto específico da política consiste sempre na organização de oposições de vontade, sobre a base de uma comunidade de vontade"; finalmente, Jean Meynaud (1960, p. 33) diz que "a política representa, em seu sentido mais geral, a orientação dada à gestão dos negócios da comunidade", bem como "o conjunto dos atos e das posições tomadas para impelir em um rumo determinado a estrutura e a marcha do aparelho governamental". Para José Jairo Gomes (op. cit., p. 2), "a política relaciona-se a tudo o que diz respeito à vida coletiva". Fechamos com Sahid Maluf (1984, p. 370), donde se extrai que a política é a interferência "na solução dos magnos problemas nacionais e na própria direção do Estado".

Vale enriquecer essa conceituação com a reprodução dos princípios que Joel José Cândido (2004, p. 153) arrolou para a propaganda política: princípio da legalidade, princípio da liberdade, princípio da responsabilidade, princípio igualitário, princípio da disponibilidade e princípio do controle judicial da propaganda.

Com essa base, podemos considerar que a propaganda política é aquela voltada às atividades coletivas, sejam elas oriundas do governo, sejam elas visando o governo, sejam elas relativas à esfera de atuação do governo. Essa órbita governamental é ampla, porque há de se entender que a política pode não estar necessariamente no exercício do poder, mas no seu entorno, como no caso dos partidos políticos, das organizações do terceiro setor, e dos movimentos sociais.

\subsubsection{Propaganda institucional}

Por sua vez, a propaganda institucional é destinada a divulgar atos de governo com relevância jurídica.

Está referida no art. 37 da Constituição como "publicidade dos atos, programas, obras, serviços e campanhas dos órgãos públicos”, devendo ter "caráter educativo, informativo ou de orientação social, dela não podendo constar nomes, símbolos ou imagens que caracterizem promoção pessoal de autoridades ou servidores públicos". O sujeito ativo será sempre o Poder Público.

Essa é uma norma das mais desvirtuadas. É bem usual a promoção de obras e realizações governamentais de todas as esferas, com feições de promoção pessoal, sem qualquer utilidade ou necessidade de interesse público. O que dizer de uma propaganda em rádio, TV, jornal ou internet 
que, ao custo de milhões de reais, diz que foram asfaltadas tantas vias e que o governo tal "está trabalhando por você"? Propaganda pessoal com dinheiro público, nada além. Típico ato de improbidade administrativa. Mas isso já é tema para outro momento.

\subsubsection{Propaganda intrapartidária}

A propaganda intrapartidária é aquela havida no âmbito das agremiações por ocasião das convenções que elegem candidatos e celebram coligações. $\mathrm{Na}$ maior parte, somente grandes colégios eleitorais adotam essa espécie, já que, em geral, a propaganda interna em pequenos grupos não justifica o investimento.

\subsubsection{Propaganda partidária}

A propaganda partidária, por sua vez, é destinada a propagar o partido e suas ideias e atividades, não seus candidatos.

A propaganda partidária já era reconhecida desde o Brasil Império, havendo menção nas consideranda do Decreto 1.574, de 20 de outubro de 1893, e dali em diante foi sendo sempre referida na legislação; a Lei 5, de 14 de dezembro de 1946, regulando as eleições de 1947, permitia a "propaganda política" no rádio, desde que fosse remunerada.

O Código Eleitoral de 1950 (Lei 1.164, de 24 de julho de 1950), no art. 129, 6, dispunha sobre atos de propaganda "partidária ou eleitoral", e no art. 130 previa a propaganda "partidária” remunerada por duas horas diárias no rádio durante os noventa dias antecedentes à eleição. Ao que tudo indica, houve intenção de tratar de propaganda eleitoral, já que referente a período de campanha.

Já o art. 151 encabeçava o capítulo VII, da "Propaganda Partidária", que no número 3 permitia aos partidos "fazer a propaganda própria ou dos seus candidatos”. Já a propaganda partidária gratuita em radiodifusão (rádio e televisão) só veio ao Brasil por conta do art. 118, III da Lei 5.682, de 21 de julho de 1971 (Lei Orgânica dos Partidos Políticos), que assim previa:

“Art. 118. Os partidos terão função permanente através:

(...)

III - da promoção de congressos ou sessões públicas para a difusão do seu programa, assegurada a transmissão gratuita, pelas empresas de rádio e televisão; (...)" 
A mais recente regra estava contida na Lei 9.096, de 19 de setembro de 1995 (Lei dos Partidos Políticos), que nos arts. 45 a 49 dispunha sobre o Título IV (do acesso gratuito ao rádio e à televisão), em consonância com o texto constitucional.

Vivíamos fase de estável separação entre propaganda eleitoral e partidária, inobstante esta tivesse sendo usualmente distorcida para atingir as finalidades daquela.

Diz Alexandre Jobim (2008, p. 148):

A propaganda partidária é, ou deveria ser, aquela destinada aos partidos políticos para que lançassem as suas ideologias, anseios, propostas, justamente em caráter regulamentar ao art. 17 da vigente Carta da República.

O art. 17 a que se refere o autor não usa a expressão "propaganda partidária”, mas faz menção ao "acesso gratuito ao rádio e à televisão".

A Lei 13.487, de 6 de outubro de 2017, pôs fim à propaganda partidária no rádio e na televisão, tal como a conhecíamos, a partir de 2018. A previsão constitucional de "acesso gratuito ao rádio e à televisão", conhecido como direito de antena, permanece no art. 17 da Carta.

\subsubsection{Propaganda eleitoral}

Finalmente, tem-se a propaganda eleitoral. Wolney Ramos (2005, p. 33) relata que ela começou a se institucionalizar sob o aspecto mercadológico na década de 50 nos Estados Unidos:

Os programas eleitorais para o rádio e a televisão começaram a requerer certo planejamento e adoção de medidas estratégicas - era o marketing político surgindo no cenário eleitoral. Já em 1952, o General Eisenhouwer foi o primeiro candidato a contratar uma agência de publicidade, chamada BBDO, para a realização de sua propaganda na televisão, sendo acusado na época de 'tentar se vender como se vende um sabonete'. Em 1956, o marketing político já se tornava um instrumento obrigatório para uma campanha presidencial nos Estados Unidos, e a partir de então passou a ser adotado também em outras partes do mundo cujas organizações políticas fossem baseadas na democracia representativa. 
No Brasil, com relação à legislação sobre propaganda eleitoral via radiodifusão, a primeira menção veio no Código Eleitoral de 1935 (Lei 48, de 4 de maio de 1935), não positivando seu exercício mas vedando-o nas 48 horas anteriores ao pleito e 24 horas após.

Vejamos, pois, o que é a propaganda eleitoral.

\subsubsection{Conceito}

A definição de José Jairo Gomes (op. cit., p. 482) é robusta:

Denomina-se propaganda eleitoral a elaborada por partidos políticos e candidatos com a finalidade de captar votos do eleitorado para investidura em cargo público-eletivo. Caracteriza-se por levar ao conhecimento público, ainda que de maneira disfarçada ou dissimulada, candidatura ou os motivos que induzam à conclusão de que o beneficiário é o mais apto para o cargo em disputa. Nessa linha, constitui propaganda eleitoral aquela adrede preparada para influir na vontade do eleitor, em que a mensagem é orientada à conquista de votos.

Djalma Pinto (op. cit., p. 242) assim conceitua:

A propaganda eleitoral é aquela feita por candidatos e partidos políticos, objetivando a captação de voto para investidura na representação popular. Está intimamente relacionada com o processo eletivo, visando obter a simpatia do eleitor por ocasião da escolha de seus governantes.

Para diferenciá-la da propaganda política, Coneglian (2012, p. 31), diz que "a propaganda eleitoral é aquela dirigida diretamente à conquista do sufrágio para determinada e precisa eleição. A propaganda política busca adepto para uma ideia, uma ideologia, um partido, uma corrente. A propaganda eleitoral busca a conquista do eleitor e de seu voto."

Numa linha diferente desses doutrinadores, Ramayana (2008, p. 53) oferece uma definição um tanto mais ampla, porque não restringe a propaganda eleitoral à captação de votos:

Trata-se de espécie de propaganda que tem a finalidade precípua de divulgar ideias e programas dos candidatos. É a oportunidade que a legislação eleitoral atribuiu ao candidato para exteriorizar o símbolo real do mandato representativo e partidário. 
A jurisprudência do Tribunal Superior Eleitoral (STE) tem acórdão da lavra do ministro Eduardo Alckmin (BRASIL, 1999) com um conceito igualmente aberto:

Entende-se como ato de propaganda eleitoral aquele que leva ao conhecimento geral, ainda que de forma dissimulada, a candidatura, mesmo que apenas postulada, a ação política que se pretende desenvolver ou as razões que induzam a concluir que o beneficiário é o mais apto ao exercício de função pública.

Ao optar por elastecer o conceito, abandonando a restrição à conquista de votos, esses últimos entendimentos melhor explicam a propaganda eleitoral, porque não circunscrevem sua finalidade à eleição em si, abrindo-a à candidatura em toda a sua extensão.

Mas pensamos que a propaganda eleitoral não está adstrita ao pedido de votos e nem apenas à candidatura. Vai além, vai ao campo ideológico, às causas, tal qual a propaganda partidária ou a propaganda política lato sensu. E não se diga que sendo assim deixaria de ser eleitoral. O que torna a propaganda eleitoral, nesse particular, é o fato de se dar no bojo de um pleito, mas isto não impede que sua finalidade possa ser mais ampla que o resultado da eleição. Não é só de voto que se cuida. Vejamos.

A propaganda se insere num processo que ordinariamente culmina em um resultado de votação, mas resulta em muitas outras consequências além da eleição em si. O sistema eleitoral como um todo abriga a construção permanente de um ou alguns ideários nacionais acerca da própria concepção de democracia. Ao longo dos reiterados pleitos, com suas peculiaridades, idas e vindas, pelo menos três grandes forças vem interagindo no curso da história.

A primeira força vem dos atores do mundo jurídico, juízes, promotores, advogados, serventuários, acadêmicos e outros mais, que vão consolidando uma base jurisprudencial e doutrinária, reconhecidamente legítima fonte de direito. A segunda força é dos representantes da imprensa e da comunicação em geral, que vão compondo um arcabouço de informação acumulada e um direcionamento da opinião pública, com todas as ferramentas tecnológicas de que dispõem, num mundo cada vez mais hiperinformado e onde, portanto, a influência da comunicação é gigantesca. Por fim, a terceira força está no eleitorado, que ajuda a erguer esse patrimônio cultural que é a 
noção de soberania popular, o sentimento de civilidade, o pertencimento ao Estado, numa ininterrupta dinâmica de movimentos ativos e passivos, em que tanto recebem e são moldados quanto se manifestam e vão moldando o soberano conjunto popular.

Nesse panorama, uma eleição é apenas um ato do macroprocesso, que acaba não sendo um fim em si mesmo, mas instrumento para algumas finalidades. Há partidos muito antigos que jamais chegaram a ter expressão nacional, outros que a perderam, outros ainda que sequer têm histórico de candidaturas que justifique um plano de expansão, o que demonstra que suas metas não são um determinado resultado eleitoral.

No espectro ideológico posto ao longo da história, há muitas militâncias que encerram causas, muito além de interesses partidários. Os chamados partidos-movimento são exemplos disso, mas não apenas esses. Desde o maior especialista ao mais ignorante eleitor, todos sabem que há muitas situações em que certas candidaturas não têm expectativa real de sucesso, e ainda assim elas são mantidas.

Esses casos, em geral, se justificam pela visibilidade do partido, pelo cumprimento de compromissos regionais, pela manutenção de uma bandeira atemporal ideológica, pela pura defesa de uma causa ou por alguma outra estratégia.

O Partido da Causa Operária (PCO) foi típico exemplo, quando nas eleições de 2018, em muitos casos, demonstrou nitidamente não estar preocupado com arregimentação de votos. Em Santa Catarina, por exemplo, o candidato ao governo estadual teve reduzida participação na mídia, deixando de aparecer mesmo quando tinha oportunidade, e quando o fazia não enfatizava sequer o pedido de voto - inclusive por entender que a eleição seria "uma fraude" - mas outras mensagens paralelas, como a revolução da classe trabalhadora e a libertação do ex-presidente Luiz Inácio Lula da Silva (Ângelo, 2018). Típico exemplo de que a propaganda eleitoral não se destina exclusivamente ao sufrágio.

Apenas para contextualizar, há um dispositivo na Lei das Eleições que resulta em efeito prático na ampliação da finalidade da propaganda eleitoral. Diz o art. 26, II, da Lei 9.504/97 que é considerado gasto eleitoral sujeito a registro e aos limites legais "propaganda e publicidade, direta ou indireta, por qualquer meio de divulgação, destinada a conquistar votos". Essa expressão final, "destinada a conquistar votos", é induvidosa, qua- 
lificando a conduta. Como a lei não tem palavras inúteis, por certo essa é a melhor interpretação. Significa que se o candidato não empregou seu tempo de propaganda para pedir votos e sim para outra finalidade, como a defesa de causas, não haverá incidência do comando legal. Um sinal de que vem da própria lei e do espírito do legislador um gabarito mais amplo para o conceito de propaganda eleitoral.

Permite-se ousar um pouco mais para dizer que o conceito de propaganda eleitoral, nesse viés amplíssimo, pode admitir até mesmo manifestações de quem não seja candidato, ainda que no período e no âmbito de um processo eleitoral.

É o caso das peças produzidas pela Justiça Eleitoral quando convoca a população a regularizar o título, a participar da eleição, a buscar informações sobre os candidatos. Mais especificamente, há a possibilidade de requisição de horários de até dez minutos diários de rádio e televisão, trinta dias antes do período de propaganda e nos três dias antes da eleição, para que a Justiça Eleitoral possa divulgar "comunicados, boletins e instruções ao eleitorado", conforme dispõe o art. 93 da Lei das Eleições.

Existe ainda a hipótese do art. 56, \ $1^{\circ}$, em que no caso de suspensão de funcionamento de emissora por 24 horas, em face de infração cometida, a cada quinze minutos "a Justiça Eleitoral veiculará mensagem de orientação ao eleitor".

São situações em que evidentemente há informação ao eleitor, de cunho persuasivo, relativas ao processo eleitoral, que contribuem sobremaneira à democracia, e que se somam ao conjunto de informações disponíveis, mas nesse caso produzidas oficialmente, com previsão legal expressa. Essa, entretanto, já é uma digressão, e o tema merece melhor investigação em outro momento. Cabe aqui apenas ressaltar a amplitude do conceito de propaganda eleitoral.

Assim, pode-se considerar que a propaganda eleitoral é a propaganda política realizada no seio de um processo eleitoral, que compreende todos os momentos relativos às eleições, desde os atos preparatórios até a diplomação dos eleitos. Dizendo de outro modo, a propaganda eleitoral é a divulgação com fim persuasivo de determinada mensagem no curso de um processo eleitoral. 


\subsubsection{Tipos de propaganda eleitoral}

José Jairo Gomes (2016) apresenta três classificações para a propaganda eleitoral: "forma de realização, sentido e momento em que é levada a efeito" (op. cit., p. 483)

Acerca da forma de realização divide-a em expressa ou subliminar. A primeira é aquela mais evidente, clara, de fácil compreensão, sem artifícios que possam tender a uma influência camuflada. A propaganda subliminar, por sua vez, nas palavras do autor (loc. cit.), compreende

estímulos de conteúdo político-eleitoral inseridos em um discurso (ou em uma comunicação) que, porém, não são percebidos conscientemente pelos destinatários. No Direito Eleitoral, ela é associada à comunicação político-eleitoral disfarçada, ambígua, que se encontra subjacente ao discurso que a envolve.

Esse tipo é deveras interessante ao presente debate, porque diz respeito à possibilidade de manipulação do eleitor. Cabe observar que a Lei das Eleições não ignora a possibilidade de propaganda subliminar, embora não tenha disposição expressa e direta; há referência à propaganda feita "dissimuladamente" em programas de rádio e televisão (art. 45, V) e ainda vedação à veiculação, no horário eleitoral gratuito em rádio e televisão, de propaganda com fins comerciais, "ainda que disfarçada ou subliminar" (art. 44, \ $2^{\circ}$ ).

Quanto ao sentido, prossegue Gomes (op. cit., p. 484):

Pode a propaganda ser positiva ou negativa. Naquela, exalta-se o beneficiário, sendo louvadas suas qualidades, ressaltados seus feitos, sua história, enfim, sua imagem. (...) Já a propaganda negativa tem por fulcro o menoscabo ou a desqualificação dos candidatos oponentes, sugerindo que não detém os adornos morais ou a aptidão necessária à investidura em cargo eletivo.

Finalmente, com relação ao momento de realização, a propaganda pode ser tempestiva ou extemporânea, diz o autor, conforme tenha sido realizada dentro ou fora do período permitido pela legislação eleitoral.

Há ainda outra possibilidade de classificar a propaganda, segundo os tipos pelos quais ela é veiculada. Assim, tem-se propaganda em radiodifusão (rádio e televisão), que é o ponto focal deste trabalho, propaganda em impressos, em bandeiras, adesivos plásticos, propaganda em outdoor 
(proibida), em carro de som, em reuniões, passeatas e carreatas, imprensa, mídia escrita, internet, dentre outros.

A lei não tem uma abordagem sistematizada dos tipos de propaganda, não há uma organização no texto, e muito menos consegue esgotar as possibilidades.

Basta pensar, por exemplo, na perfumaria como meio de propaganda. Um perfume é estimulante de sentidos, afeta a memória olfativa e se adotado com estratégia é meio muito eficaz. Obviamente que uma mensagem para seres humanos não depende exclusivamente de palavras, e portanto, as variantes são imensas. Mas esse caso, por exemplo, não tem previsão legal e nem está sujeito a alguma forma de controle evidente, até porque a legislação não considerou a hipótese.

\subsubsection{Regramento}

As regras do jogo não são poucas e nem genéricas quando se trata de propaganda eleitoral. Inobstante as minúcias, vamos analisar apenas o que importa a este estudo, considerando as disposições da Lei 9.504/97. A Lei das Eleições dedica 40 artigos à propaganda eleitoral, dos quais se pode considerar dois grandes grupos, embora haja artigos contendo dispositivos de ambos, aqui classificados segundo a predominância.

No primeiro, que se pode chamar de "Grupo da Configuração", com 29 artigos, encontram-se regras sobre tipos, formas e condições, sobre lugares, horários e períodos permitidos, sobre a propaganda em relação a bens públicos ou de uso comum, sobre a gratuidade ou possibilidade de pagamento, sobre restrições à liberdade de expressão quando à forma (trucagens etc.) e à origem (radiodifusão), sobre debates - forma indireta de propaganda, sobre direito de resposta - mecanismo de correção da propaganda, e sobre campanha de boas práticas na internet pela Justiça Eleitoral.

No “Grupo da Disciplina”, são 11 artigos tratando de ilicitudes na propaganda eleitoral, responsabilidades pela realização, benefício, anuência ou ciência da propaganda, e ainda sanções para emissoras, provedores, candidatos, partidos, coligações, eleitores e terceiros por atos relativos à propaganda.

O art. 41-A, que trata de captação ilícita de sufrágio, parece estar geograficamente deslocado, já que se localiza no subtítulo "Da propaganda eleitoral em geral", mas não trata de propaganda eleitoral e sim de atos de deliberada fraude ao sistema. 
Interessa ao presente estudo a abordagem de alguns dispositivos que dizem respeito a aspectos ligados à disponibilidade do espaço para propaganda e a correlação disso com nossa conclusão, que é o tempo mínimo de propaganda. Para tanto, não serão elencados todos os artigos sobre propaganda eleitoral. Vale ressaltar, todavia, que o conjunto de dispositivos revela uma norma nitidamente restritiva à propaganda eleitoral. Veda-se muito, restringe-se muito, limita-se muito, talvez no afã de coibir abusos, mas certamente essa redução de possibilidades acaba também inviabilizando parcela importante da comunicação entre eleitor e candidato.

Por exemplo, proíbe-se a imprensa da radiodifusão de tomar partido emitindo opiniões, mas ao mesmo tempo se dá às emissoras o poder de vetar em debates os candidatos que não estejam contemplados na cláusula de barreira (partidos com pelo menos cinco parlamentares).

Então, um candidato de partido recém-fundado ou com curto tempo de vida, ou ainda que não tenha expressivos resultados nas urnas, simplesmente não tem espaço. Isto se dá em debates, se dá na proporcionalidade em entrevistas e no próprio horário eleitoral gratuito. A fórmula contempla a preservação de quem já conquistou o poder.

Outro exemplo: as especificações técnicas para produção e veiculação da propaganda eleitoral gratuita. São tantas exigências, incluindo o uso de mídias físicas específicas para determinadas emissoras e serviços especializados, que a propaganda não é nem de longe gratuita. De início, a Lei 13.146/2015, que trata de acessibilidade, impõe na conjugação do art. 67 com o art. 76, \ 1으. III, o uso de subtitulação por meio de legenda oculta, janela com intérprete de Libras e audiodescrição em toda a propaganda de rádio e televisão. Isso representa um custo alto, e a lei diz que "o poder público deve garantir” esses recursos (caput), mas não há regulamentação e a despesa acaba na conta dos partidos. Como é que um candidato pobre poderá arcar com esses gastos?

$\mathrm{Na}$ prática, as limitações à propaganda acabam beneficiando os partidos bem estruturados, os candidatos que já estão no poder e são conhecidos, e aqueles que têm acesso a recursos econômicos, ainda que ilegalmente. Não se quer fazer juízo de valor sobre o método escolhido pelo legislador, e nem buscar alternativas, este não é o escopo do trabalho. O que se faz é meramente constatar que a legislação restringe a propaganda e essa restrição tem seus efeitos. 
Passando à verificação dos artigos, pelo escopo do texto não cabe fazer a análise minuciosa deles todos. É bastante chamar a atenção para os quatro artigos que tratam efetivamente do que mais diz respeito ao centro do presente trabalho. São eles, os arts. 47 e 49, que cuidam da distribuição do tempo em rede de rádio e televisão, no primeiro e segundo turnos, e o art. 51, que trata da propaganda mediante inserções ao longo da programação, e ainda o art. 58, que diz respeito ao direito de resposta.

Pois bem. A propaganda em rádio e televisão é o foco deste trabalho. Radiodifusão é o serviço "a ser recebido direta e livremente pelo público em geral, compreendendo a transmissão de sons (radiodifusão sonora) e a transmissão de sons e imagens (televisão)" (RODRIGUES JÚNIOR, 2006, p. 293). Complementa Otavio Júnior: "A Constituição da República estabelece uma dicotomia entre serviços de radiodifusão e de telecomunicações, embora estes últimos possam ser vislumbrados numa relação gênero-espécie ante os primeiros" (loc. cit.).

A radiodifusão no Brasil foi inaugurada em 7 de setembro de 1922 (CASTRO, 2018), e a primeira referência legal veio com o Decreto 16.657, de 5 de novembro de 1924, tendo, segundo relata Yvonete Meneguel (2018). Mas a primeira regulamentação sistemática se deu com o Decreto 20.047, de 27 de maio de 1931, e com o Decreto 21.111, de 1 de março de 1932. Essa legislação foi pioneira, segundo Cristiano Aguiar Lopes (2011, p.3), e tais decretos constituíram até 1962 "as principais peças legais da radiodifusão" (loc. cit.). Inobstante o art. 35 do Decreto 21.111/32 viesse a tratar de responsabilidade pelo conteúdo, não havia qualquer menção ao direito de resposta.

Ébida dos Santos (2014) faz um resumo do período:

Consideramos que o uso político do rádio no Brasil pode ser dividido em três grandes momentos. O primeiro compreende de 1930 a 1945, onde através do seu regime ditatorial, Getúlio Vargas regula o sistema de rádio e o uso da propaganda, vindo a utilizá-lo para impor seus ideais políticos de unificação nacional. O momento seguinte, pós Vargas, dá início ao processo de regulação do uso dos meios de comunicação pelos partidos e candidatos, marcado novamente pela censura e cerceamento da liberdade de imprensa e de expressão, com o regime militar, que vai do golpe de 1964 até 1985. Como marco para o terceiro período, consideramos a Constituição de 1988, que restitui a liberdade de atuação da imprensa e garante acesso gratuito, 
pelos partidos políticos, ao rádio e a televisão, com a constante atualização da legislação para acompanhar cada pleito.

E aqui estamos, na era da informação.

\subsection{Propaganda como direito à informação}

A função mais importante da propaganda é a de informar. Mas é preciso considerar algumas premissas. A primeira delas: o direito de receber informação, por parte do eleitor, prevalece sobre o direito de transmiti-la, por parte do candidato. A segunda: para fins de compor um processo eleitoral legítimo e democrático, a informação deve ser qualificada, o que não diz respeito apenas a uma característica intrínseca, mas também ao entorno, ao ambiente de interlocução. Finalmente: a informação é um direito-dever do candidato.

\subsubsection{A influência da propaganda na sociedade}

A propaganda influencia a opinião pública, que por sua vez afeta o processo eleitoral, que pode gerar distorções na legitimidade do pleito e, por consequência, na própria constituição política do Estado. É crucial, portanto, prestar atenção na propaganda como um fator de aferição da qualidade do conjunto democrático. Não será jamais um mero detalhe que uns candidatos tenham acesso à propaganda e outros não.

E nesse ponto é importante observar que não basta que a propaganda seja disponibilizada conforme prevê a legislação. Não se trata de uma observância formal da lei, e sim de cuidar para que a propaganda efetivamente ocorra de um modo razoavelmente adequado.

Isto significa que a propaganda há de ser clara, compreensível ao eleitor, sem vícios que possam distorcer a verdade e que seja efetivamente realizada. Efetivamente realizada, diga-se, mesmo para o candidato que entenda não depender dela por estar bem posicionado nas pesquisas, já que, como dito alhures, a propaganda enquanto informação é direito indisponível e precisa ser realizada por conta da necessidade do eleitorado em recebê-la.

Então, reitere-se sobre o quão relevante é considerar a influência da propaganda, para o bem ou para o mal, seja seu excesso ou sua ausência, sua completude ou sua precariedade. De acordo com Melvin DeFleur (1993, p. 298) "tudo - aprendizagem, atitudes e comportamento - é de al- 
guma forma influenciado pela propaganda”. Para Bandeira de Mello (1996, p. 100), em países sem uma democracia substancial "o povo é presa fácil das articulações, mobilizações e aliciamento da opinião pública, quando necessária sua adesão ou pronunciamento, graças ao controle que os setores dominantes detém sobre a mídia, que não é senão um dos seus braços.”

E é justamente essa possibilidade de manipulação decorrente de outros elementos que nos leva à conclusão de que o tempo de propaganda pode desvirtuá-la.

\subsubsection{Liberdade de expressão na propaganda eleitoral}

Não é recente a preocupação do legislador brasileiro com a liberdade de expressão no âmbito do direito eleitoral. Encontra-se nas consideranda do Decreto 1.574, de 20 de outubro de 1893 (JOBIM, 1996, p. 450), nos primórdios da República, algumas passagens que revelam a importância da propaganda no processo eleitoral e a preocupação dos efeitos de eventual cerceamento à liberdade. Tratava-se de um adiamento das eleições de deputados e senadores daquele ano, que ocorreriam dali a dez dias, para dois meses após.

Lê-se, dentre outros, esse trecho:

que as limitações á liberdade de imprensa, indispensáveis, attentas as condições excepicionaes que atravessa a Republica Brazileira, poderão prejudicar a propaganda das ideias dos partidos difficultando-lhes a arregimentação de forças para a lucta eleitoral; que os Estados comprehendidos nas disposições do decreto $\mathrm{n}^{\circ} 1.563$ de 13 de outubro que estaleleceu o estado de sitio, onde portanto a eleição não tem as garantias constitucionaes da liberdade individual, influirão poderosamente sobre a manifestação da opinião, pelo importante numero de representantes com que concorrem para o Poder Legislativo;

Contemporaneamente, a Constituição Federal traz no art. 220 uma especial proteção à liberdade de expressão e, no que nos interessa, à informação:

"Art. 220. A manifestação do pensamento, a criação, a expressão e a informação, sob qualquer forma, processo ou veículo não sofrerão qualquer restrição, observado o disposto nesta Constituição.

$\int 1^{\circ}$ Nenhuma lei conterá dispositivo que possa constituir embaraço à plena liberdade de informação jornalística em qualquer veículo de 
comunicação social, observado o disposto no art. 5ª, IV, V, X, XIII e XIV.

$\S 2$ É vedada toda e qualquer censura de natureza política, ideológica e artística.

$\int 3^{\circ}$ Compete à lei federal:

I - regular as diversões e espetáculos públicos, cabendo ao Poder Público informar sobre a natureza deles, as faixas etárias a que não se recomendem, locais e horários em que sua apresentação se mostre inadequada;

II - estabelecer os meios legais que garantam à pessoa e à família a possibilidade de se defenderem de programas ou programações de rádio e televisão que contrariem o disposto no art. 221, bem como da propaganda de produtos, práticas e serviços que possam ser nocivos à saúde e ao meio ambiente.

$\int 4^{\circ} \mathrm{A}$ propaganda comercial de tabaco, bebidas alcoólicas, agrotóxicos, medicamentos e terapias estará sujeita a restrições legais, nos termos do inciso II do parágrafo anterior, e conterá, sempre que necessário, advertência sobre os malefícios decorrentes de seu uso.

$\int 5^{\circ}$ Os meios de comunicação social não podem, direta ou indiretamente, ser objeto de monopólio ou oligopólio.

$\int 6^{\circ}$ A publicação de veículo impresso de comunicação independe de licença de autoridade."

Se no $\int 1^{\circ}$ há referência à informação da espécie "jornalística”, o caput traz o gênero informação, mais abrangente, que vai garantir todo o conjunto de conhecimento possível de ser transmitido ou acessado e que pode vir a ser objeto da tutela constitucional.

Essa informação está sob a guarida da lei - lato sensu - porque não interessa apenas ao emissor, mas a todo o processo da comunicação que, em última análise, vai viabilizar a dinâmica social em que se inserem os direitos fundamentais.

Vem da jurisprudência uma lição sobre a natureza da liberdade de expressão, em acórdão da lavra do juiz Harrison Targino (2002):

A liberdade de imprensa e de expressão não é dada dos meios de comunicação ou dos jornalistas, mas em favor de toda a sociedade na medida em que é desta o interesse por informações livres. 
A liberdade de expressão é um direito fundamental declarado na Constituição, com garantias constitucionais vinculadas, diz Carlos Neves Filho (2012, p. 25).

\subsubsection{A integridade da informação}

A informação compõe a comunicação, que pressupõe mão dupla entre os interlocutores. É o que diz o relatório Many Voices One World, documento elaborado pela UNESCO em 1980 sobre problemas de comunicação no planeta e que ganhou o título, no Brasil, de Um Mundo e Muitas Vozes (UNESCO, 1983).

Concebida como um dos direitos humanos da terceira geração (ALCURI, 2012), o direito de se comunicar é evidentemente mais amplo do que o de informar ou ser informado, porque unidirecionais, especialmente nos veículos que interessam ao debate - rádio e televisão.

"Tudo comunica: tudo o que você faz ou deixa de fazer ou diz ou deixa de dizer", lembra o marqueteiro mexicano Sergio Zyman (2003, p. 12). Até o silêncio, diz Eni Orlandi (1996, p. 263), "tanto quanto a palavra, tem suas condições de produção; por isso dada a diversidade dessas, o sentido do silêncio varia, isto é, ele é tão ambíguo quanto as palavras. (...) Por outro lado, o silêncio pode produzir uma ruptura não desejada. Inscreve-se nesse caso aquilo a que se chama ruído da comunicação." O que se denota é a amplitude potencial da comunicação, que não se limita a uma monocórdica troca de dados. Mais razão para considerar que todas as nuances da comunicação importam, inclusive - e é aonde queremos chegar - a questão do tempo necessário para uma transmissão razoável.

De todo modo, deixemos a comunicação para focar a informação. A concepção de um modelo de comunicação participativo, interativo e, portanto, democrático, nos conduz a um conceito mais elaborado de informação. É preciso abstrair a ideia de transmitir dados, conhecimento, mensagem, para reinseri-la num contexto em que outros elementos devem ser levados em conta, como o emissor, o receptor, as condições destes e da transmissão. A informação deve ser assim compreendida, sob pena de não conseguir entender os efeitos das suas distorções ou deficiências.

Melo (1986, p. 70) lembra Paulo Freire para falar do silêncio como fruto da falta de acesso à educação e à informação, e lembra que mesmo quando há o acesso o sistema é falho, limitado a uma "mera transferência de informações", no que chama de "pedagogia do antidiálogo". 
Essa passagem nos ajuda a compreender que a informação que tanto perseguimos, como direito do eleitor e como elemento fundamental da democracia, não é a simples transmissão de dados, longe disso. O que parece ser mais adequado é - fazendo essa leitura com base nos princípios constitucionais e eleitorais já vistos - buscar uma informação íntegra como parâmetro aceitável.

Para fazer um paralelo muito simples, basta pensar na hipótese de um pai ou uma mãe orientando uma criança acerca dos riscos de uma determinada atividade. Não se imagina que o responsável se dará por satisfeito em transmitir formalmente a informação sem estar convicto de que ela era compreensível; ele saberá identificar se a informação foi íntegra.

Informação íntegra, para efeito do raciocínio que se desenvolve, seria aquela idealizada como conjunto de conhecimentos não necessariamente recebidos, mas pelo menos disponibilizados num ambiente em que o emissor age com transparência e lealdade, e o receptor tenha razoáveis condições de compreender a mensagem e sobre ela exercer uma avaliação crítica. Além disso, o objeto da informação deve estar acondicionado num meio adequado.

Assim, no processo de comunicação, mesmo a informação pura é um amálgama composto por pelo menos quatro elementos: emissor, receptor, meio e mensagem. A inconsistência de qualquer um deles afetará o conjunto e, por consequência, o resultado final.

Nessa linha, pelas mesmas razões que Freire se reportava ao silêncio e Melo ao antidiálogo, a problemática da falta de informação (ou informação insuficiente ou inapta) revela que é impossível a produção de informação para os fins da propaganda eleitoral quando o espaço não for minimamente razoável. Vamos além.

Se propaganda pela metade é nenhuma propaganda, meia mensagem pode ser pior que nenhuma mensagem, porque eventualmente estará comprometida pela distorção e o efeito pode até ser reverso.

Imagine uma peça de propaganda que aborde um tema complexo ou polêmico; sem tempo suficiente, a questão pode resultar em um cenário confuso, e o prejuízo não será apenas do candidato, mas principalmente, mais uma vez, do eleitor. 


\subsubsection{O candidato e seu direito indisponível de informar}

No tocante ao direito de informar, o candidato também está amparado, por óbvio, naquele que é o mais natural mister da propaganda, a difusão de ideias. Eis a liberdade de expressão e opinião como direito fundamental e sustentáculo da democracia, mas em se tratando de propaganda eleitoral é necessário ir um tanto além.

Um candidato não representa a si mesmo. Dado o sistema partidário, como já visto, e considerando que a candidatura é monopolizada pelas agremiações, esta pretensão jurídica resulta de um processo jurídico-político. O candidato será, pois, representante de um partido ou coligação, que por sua vez, sujeitou-se a uma convenção soberana, que derivou de um ordenamento estatutário, que foi submetido ao crivo da lei e adotou determinada posição pública.

Nesse contexto, pode-se dizer que o exercício do direito à candidatura é pessoal, mas não a ela em si, que pode eventualmente vagar, mas, estando titularizada, deve obediência aos princípios constitucionais e eleitorais aplicáveis.

Tira-se daí que a propaganda eleitoral do candidato acaba sendo um direito-dever, ou até mesmo um direito indisponível. Não se trata de um ato de reflexos meramente particulares, e sim de interesse público, porque havido no seio de um processo democrático. Quer-se com isso dizer que a propaganda eleitoral é antes de tudo um dos pilares da eleição, porque subsidia o eleitor e guia a vontade popular.

Vem em socorro desta inferência a lição de José Afonso da Silva (2007, p. 41), segundo o qual "nas democracias de partido e sufrágio universal, as eleições tendem a ultrapassar a pura função designatória, para se transformarem num instrumento pelo qual o povo adere a uma política governamental e confere seu consentimento, e por consequência, legitimidade, às autoridades governamentais. Ela é, assim, o modo pelo qual o povo, nas democracias representativas, participa da formação da vontade do governo e do processo político."

Mutatis mutandis, traz-se à colação o magistério de Guilherme Gonçalves (2008, p. 232):

Entretanto, num regime democrático representativo como o definido constitucionalmente para o nosso país, onde o partido político tem o monopólio de acesso ao poder institucional, a garantia da am- 
pla liberdade de convencimento - e portanto, de realização de propaganda eleitoral - tem importância essencial para, de fato, permitir não só a existência efetiva de uma oposição legítima mas, sobretudo, que essa oposição possa, em algum momento, tornar-se situação.

A propaganda eleitoral é o veículo da informação, que por sua vez não é fim em si mesmo, mas sim um meio de proporcionar legitimidade ao processo. A informação, assim, é o alimento da soberania popular. Daí porque, reafirme-se, o direito de informar é indisponível.

\subsubsection{O eleitor e o direito de ser informado}

O ex-ministro do Tribunal Superior Eleitoral, Henrique Neves da Silva (2018), com suas costumeiras elucubrações de alto calibre, a um tempo profundas e pragmáticas, expõe com precisão a relação entre o direito à informação e o processo democrático em que se insere:

A qualidade de uma democracia depende, dentre outros aspectos, do direito à informação e da livre manifestação do pensamento. Assim, a propaganda eleitoral não pode ser compreendida apenas como uma ferramenta voltada aos interesses dos candidatos selecionados pelos partidos políticos. Ela existe principalmente para que o eleitor possa ter as informações necessárias e verídicas sobre quem são as pessoas que disputam o pleito e quais são as ideias e propostas defendidas.

Defleur (op. cit., p. 310) relembra o poder da informação:

Mas se as comunicações de massa podem modificar significados e influenciar sem querer o comportamento, há base suficiente para se procurar uma estratégia de construção de significados com a finalidade de deliberadamente alterar o comportamento. A informação dada pela comunicação de massa deve ser tão eficiente quanto qualquer outra para mudar os significados atribuídos pelas pessoas a alguma coisa, produto, causa, candidato ou questão. Se tais mudanças podem ser obtidas, daí devem decorrer modificações de comportamento no sentido daquele alvo de persuasão.

É preciso compreender a propaganda eleitoral como uma garantia ao direito de informação do eleitor, e considerar esse direito no arcabouço de um sistema democrático. A garantia ao direito de informação do eleitor 
não é apenas muito relevante, é essencial, é indispensável para que se tenha um processo eleitoral minimamente legítimo. Trata-se de uma garantia, por evidente, já que o direito em si é subjetivo.

José Marques de Melo (1986, p. 61) disse algo que parece óbvio: "Os cidadãos não têm conhecimento porque não lêem e não lêem porque não têm conhecimento para motivá-los à leitura. E consequentemente ficam à mercê das manipulações políticas, das mistificações culturais, das armadilhas econômicas." Ele discorre sobre um "comportamento passivo, acrítico, que imobiliza grande parte da sociedade", para então concluir sua insurgência quanto ao modelo vigente (op. cit., p. 65):

Um povo que não tem experiência de participação, de intervenção na coisa pública, de exercitação da sua capacidade de influir nas decisões nacionais, é um povo condenado à marginalização social e política, a permanecer mudo, silencioso, apático. A ausência de participação popular nos destinos do país e a consequente castração das potencialidades comunicativas do nosso povo tem sido uma constante na história do Brasil, da Colônia ao Império, da velhíssima República às novas Repúblicas deste século.

Para Milton Wagner da Silva (2016, p. 16), há três subdivisões para classificar a liberdade de informação: informar, se informar e ser informado:

É possível constatar três dimensões da liberdade de informação em geral: direito de informar, coincidindo com a liberdade de manifestação de pensamento pela palavra, por escrito ou qualquer outro meio de difusão; direito de se informar, ou direito de acesso à informação, o qual consiste na possibilidade de buscar informação por meio de todos os meios lícitos disponíveis; e direito de ser informado, um direito transindividual de receber informações dos Estados e dos meios de comunicação, a fim de possibilitar o exercício consciente das liberdades públicas. (op. cit., 2016, p. 16)

Para facilitar a compreensão deste trabalho, vamos considerar numa mesma vertente o binômio se informar/ser informado. Entende-se perfeitamente a distinção, que é adequada, mas como o objeto deste estudo é a propaganda de rádio e televisão e sua forma, a postura ativa do eleitor fica prejudicada, dada a já referida característica unidirecional da informação na espécie. 
O direito de ser informado é o que sustenta a tese, porque o eleitor exerce um papel passivo, de receptor; o direito de se informar, por outro lado, embora igualmente presente, tem uma presença secundária, subsidiária, porque no caso da propaganda de rádio e televisão só seria viável o exercício do direito de se informar se, de algum modo, fosse suprimido o de ser informado.

\subsubsection{O papel da informação}

A importância da informação é reconhecida há tanto tempo que já se fez presente nas primeiras normas da legislação eleitoral brasileira, ainda quando o Brasil pertencia a Portugal. O Regimento de 10 de maio de 1640, complementando as disposições do título 67 do livro 1ํ das Ordenações Filipinas, trazia instruções sobre eleição de juízes, vereadores, procuradores e outros oficiais municipais. O sistema era formatado em graus, com prévia escolha de eleitores qualificados, e uma concentração absoluta de poderes pela Coroa portuguesa.

Não se encontra aí a expressão de um amplo processo democrático, dadas as óbvias restrições e exclusões, mas desde então é possível identificar a relevância da informação sobre os candidatos no processo eleitoral. Vide o capítulo III:

E tanto que tiveres feito o dito caderno, com os títulos apartados das ditas pessoas, vos mando, que na margem do título de cada uma delias informeis por vossa letra por informação partícular, que tomareis das partes, e qualidades da tal pessoa, e se tem zelo, sufficiencia, e talento para bem servir nos officios da governança, e se é bem acostumado, e quieto, e se tem algum homizio, ou outro defeito, de que os informadores não tiverem informado; o que fareis com toda a clareza, e distíncção, dando a razão, e motivos, dos impedimentos, que lhes pozeres á margem. (JOBIM, 1996, p. 21)

O dispositivo menciona inclusive a possibilidade de um segundo levantamento de informações que tivessem escapado ao primeiro, como forma de ampliar ao máximo o espectro disponível. A informação, desde a era colonial, sempre esteve no centro das preocupações da legislação eleitoral. A propósito da colônia brasilis, Carlos Neves Filho (op. cit., p. 25) discorre sobre o direito de antena em Portugal: 
Tempo de antena, na doutrina portuguesa, é o direito à comunicação concedido aos partidos políticos e organizações sociais, sindicais, profissionais e representantes de categorias econômicas; bem como o direito à comunicação partidária da oposição constitucionalmente organizada, em contraposição aos tempos do Governo e o próprio horário eleitoral.

Esta é uma formatação amplíssima do sistema de informação ao eleitor, que privilegia as organizações sociais e catalisa as diferentes forças democráticas, num processo que dá envergadura ao exercício da soberania popular. Bruno Gonçalves (2006) considera esse modelo "um avanço notável para a democratização das comunicações".

Retornando ao ponto de partida: o direito de ser informado passa pela compreensão de que a liberdade de expressão pressupõe a responsabilidade do emissor e a capacidade do receptor, para que o processo tenha condições de fluir a contento. A comunicação não pode ser meramente formal, e nem a informação, é preciso contar com um conteúdo real, legítimo, palpável, compreensível, e esse é um direito inafastável do eleitor. Sem informação, todo o resto fica absolutamente prejudicado.

\subsection{Distribuição do tempo de rádio e TV}

A propaganda eleitoral por meio de radiodifusão (rádio e televisão) tem um tratamento legal diferenciado dos demais meios, por duas razões singelas. Primeiro, trata-se de um serviço público prestado por meio de concessão estatal. Depois, o espaço de propaganda disponível é fisicamente limitado. Essas duas características mudam a regra do jogo, e constituem uma das razões que sustentam a conclusão do presente trabalho.

Dispõe o art. 157 da Lei 9.472/97 (Lei das Telecomunicações) que "O espectro de radiofrequências é um recurso limitado", porque existem faixas limitadas nas quais se enquadram as frequências de transmissão para as diferentes formas de telecomunicação, aí inclusos os serviços de radiodifusão sonora (rádio) e de sons e imagens (televisão). Para que se tenha uma noção, existem 103 frequências de rádio FM e 66 da chamada TV aberta (UHF e VHF), que são aquelas, na iniciativa privada, sujeitas à obrigatoriedade da transmissão da propaganda, nos termos dos arts. 47 e 57, da Lei das Eleições. 
Com tão estreito leque, para um país de dimensões continentais, a limitação é evidente, razão pela qual a concessão se dá por meio de processo licitatório, pagamento de altas somas a título de outorga e um procedimento administrativo complexo, lento e burocrático. A burocracia da concessão e a limitação do espectro frequencial restringem o acesso a essa atividade. Sendo assim, uma parcela ínfima da população tem esse poder, razão pela qual o serviço é conduzido com severas restrições de controle de forma e conteúdo pela legislação pertinente.

Ericson Scorsim (2009) considera o serviço como de interesse público, e vai além: "O serviço público de televisão á a garantia constitucional para a realização de diversos direitos fundamentais". Anderson Alarcon (2005) lembra a função social dos meios de comunicação, ao lado de José Afonso da Silva (op. cit., p. 250). Inegável o papel desses meios de comunicação no exercício dos direitos fundamentais, razão pela qual se pode considerar plenamente justificado, também por isso, o tratamento diferenciado na legislação.

O outro motivo pelo qual a radiodifusão é tratada de forma especial está na limitação física do espaço disponível para a propaganda eleitoral. Um jornal pode aumentar a quantidade de suas páginas impressas, se necessário. A internet não tem limites para a inclusão de mais e mais conteúdo. Mas a TV e o rádio não contam com essa fronteira aberta. O tempo é finito, está limitado a uma programação diária, e não há como fabricar um excedente. Daí porque esse tempo, que é finito, escasso e, por isso, de alto custo, precisou ser distribuído de uma forma que pudesse atender à finalidade da propaganda e ao conflito de interesses dos partidos.

A Constituição Federal trata da propaganda eleitoral em rádio e TV no art. 17, $\int 3^{\circ}$ :

"s $3^{2}$ Somente terão direito a recursos do fundo partidário e acesso gratuito ao rádio e à televisão, na forma da lei, os partidos políticos que alternativamente:

I - obtiverem, nas eleições para a Câmara dos Deputados, no mínimo, 3\% (três por cento) dos votos válidos, distribuídos em pelo menos um terço das unidades da Federação, com um mínimo de 2\% (dois por cento) dos votos válidos em cada uma delas; ou

II - tiverem elegido pelo menos quinze Deputados Federais distribuídos em pelo menos um terço das unidades da Federação." 
Isso mostra que o ordenamento jurídico já parte de uma restrição marcante: a cláusula de desempenho. Apenas os partidos com determinada votação geral ou participação na Câmara dos Deputados terão acesso à propaganda eleitoral.

Descendo ao nível infraconstitucional, a Lei 9.504/97 dispõe sobre a distribuição do tempo em rede entre os partidos no art. 47 (primeiro turno) e 49 (segundo turno), conforme já relatado. A propaganda em rede é aquela realizada de forma simultânea pelas emissoras da circunscrição eleitoral, obedecendo a uma periodicidade fixada pela lei. A regra diz que para o segundo turno o tempo é dividido igualmente, o que, considerando o total de dez minutos, foge do problema do tempo inferior a um minuto, e portanto não interessa ao debate.

Além da propaganda em rede há a propaganda em inserções, segundo o disposto no também já citado art. 51. Não nos ocuparemos da propaganda em inserções porque essas têm uma característica diversa. Enquanto a propaganda em rede é concentrada, fixa, periódica, solene, e com tempo expressivo, o que a torna principal, a propaganda em inserções é difusa, variável, de periodicidade incerta, informal e com dimensão temporal ínfima (podendo corresponder a um décimo do tempo de rede no caso do segundo turno), ficando, por isso, relegada a uma condição complementária.

A distribuição do tempo de propaganda eleitoral em meios de radiodifusão se dá, como visto, em obediência à dimensão do resultado eleitoral dos partidos. É um critério de proporcionalidade. Renato Ribeiro $(2008,174)$ chama este parâmetro de "critério de legitimidade" e o justifica por conta da "excessiva proliferação de partidos", para então, fazendo-se acompanhar por diversos doutrinadores, noticiar uma crítica pontual:

A atual forma de distribuição é criticada pela falta de isonomia entre os partidos e por possibilitar a manutenção daqueles que estão no poder, ao atribuir maior tempo com base na representação parlamentar. (loc cit., p. 175)

A distribuição proporcional não é critério absoluto, inflexível, mas se sujeita aos moldes principiológicos eleitorais e constitucionais. Nas eleições de 2018, o tempo de propaganda em rede no rádio e na televisão ficou assim distribuído, em minutos, entre os candidatos à Presidência da 
República no primeiro turno, segundo dados do TSE: Geraldo Alckmin 5:32; Fernando Haddad 2:23; Henrique Meirelles 1:55; Álvaro Dias 0:40; Ciro Gomes 0:38; Marina Silva 0:21; Guilherme Boulos 0:13; Jair Bolsonaro 0:08; Cabo Daciolo 0:08; Eymael 0:08; Vera Lúcia 0:05; João Goulart 0:05; João Amoêdo 0:05.

Vê-se que dez dos treze candidatos tiveram à disposição tempo inferior a um minuto de propaganda eleitoral. E as mensagens, por certo, foram reduzidas a meros segundos de slogans, jingles ou palavras de ordem que procuravam sintetizar algum ponto enfático dos programas ou da identidade partidária, nada além. Impossível, na teoria e na prática, apresentar uma mensagem que pudesse minimamente levar ao eleitor um conteúdo, qual fosse o tema escolhido.

Não existe proporcionalidade em outros meios. Há toda uma gama de meios e veículos de comunicação, tal como em comícios, panfletagem, internet, imprensa escrita et coetera, e em todos os casos, ou há liberdade ou restrição, com igualdade para todos.

Esta peculiaridade da radiodifusão tem a ver, é certo, com a finitude do espaço disponível, em razão das características da programação, como já explanado. Pelas mesmas razões é que os debates também foram regulados com certa restrição, limitando-se o número mínimo obrigatório de participantes, e nesse caso, de acordo com a participação no Congresso Nacional.

Hipótese tão grave quanto seja a das entrevistas para televisão, rádio e até para a imprensa escrita. Os veículos por vezes adotam uma regra de proporcionalidade mista, em que dão aos mais bem posicionados em pesquisas eleitorais um espaço maior, ou ainda de acordo com a representação parlamentar, inobstante nada disso tenha previsão legal.

A jurisprudência, todavia, assim tem resolvido a questão, como no acórdão do Tribunal Superior Eleitoral proferido na representação 103246/ DF (12.09.2014), da relatoria do Ministro Admar Gonzaga Neto, abaixo, no trecho que interessa:

O art. 45, IV, da Lei nº 9.504/97 não garante espaço idêntico a todos os candidatos na mídia, mas sim tratamento proporcional à participação de cada um no cenário político. O espaço na programação dos veículos de comunicação deve ser conferido aos candidatos, tendo em vista a respectiva posição no cenário eleitoral, em conformida- 
de com o aspecto material do princípio da isonomia. Atenta contra o princípio da razoabilidade obrigar os veículos de comunicação a convidar todos os candidatos registrados e a realizar cobertura jornalística diária, impedindo-os de exercer sua atividade em função de critérios mercadológicos, desde que não desbordem para o privilégio.

O conjunto de restrições legais à propaganda, em contato com o sistema de distribuição proporcional do tempo, provoca uma reação danosa ao processo eleitoral, ao alijar parcela dos candidatos e, portanto, mutilar a legitimidade da disputa. O ambiente democrático fica, assim, fragilizado, o que reforça a necessidade de se garantir um tempo mínimo de propaganda.

\section{O tempo mínimo de propaganda em rádio e TV}

\subsection{Imprescindibilidade de um tempo mínimo}

A falta de um limite mínimo de tempo leva a um problema de situação extrema, em que o tempo disponível para a mensagem é ínfimo e, portanto, insuficiente para a comunicação razoável de um conteúdo. Encontrar essa medida é tarefa complexa, mas antes urge justificar a necessidade de se fixar esse piso de tempo. E a principal razão está na circunstância de que uma mensagem incompleta pode ser equivalente à ausência de mensagem. Dar ao espaço de propaganda um tratamento de mera formalidade pode resultar na inviabilização desta, ou de sua finalidade.

Tome-se emprestado o exemplo da regulamentação sobre publicidade, com a rica experiência do CONAR (Conselho Nacional de Autorregulamentação Publicitária), uma corporação civil que fiscaliza o setor. "Além de cumprir a regra, é preciso atingir a finalidade", diz seu ex-presidente Gilberto Leifert (2002), chamando a atenção para a aplicação da principal fonte de controle da entidade, que é o Código Brasileiro de Autorregulamentação Publicitária.

A norma (privada) traz disposições como estas, do Anexo A:

1.1 No meio Rádio, será veiculada durante fração de tempo suficiente para sua locução pausada e compreensível.

1.2 Nos meios TV, inclusive por assinatura e Cinema, quaisquer que sejam os suportes utilizados para o comercial, será veiculada em áudio e vídeo durante fração de tempo correspondente a, pelo menos, um décimo da duração da mensagem publicitária. 
A estipulação de um critério de tempo mínimo para a veiculação da mensagem publicitária demonstra o que se está a enfatizar no campo eleitoral: não é razoável considerar que uma mensagem possa ser transmitida adequadamente se não houver tempo suficiente para tal, porque esta medida será delimitadora.

Essa questão é absolutamente carente de estudos jurídicos, de modo que a missão de garimpar doutrina ou jurisprudência que contenha uma abordagem direta é inglória. Não há estudos sobre essa relação entre mensagem e tempo mínimo, e muito menos sobre a fixação de um limite inferior ideal ou eventual critério para tanto.

Não por outro motivo é preciso buscar em outros ramos do Direito ou mesmo fora do meio jurídico algumas referências que possam contribuir com a investigação. Há uma resolução da ANVISA (RDC 96/2008) que institui o Regulamento Técnico sobre Propaganda, Publicidade, Promoção e Informação de Medicamentos e estabelece a necessidade de fazer constar certas cláusulas de advertência:

Art. 23 A propaganda ou publicidade de medicamentos isentos de prescrição médica deve, também, veicular advertência relacionada à substância ativa do medicamento, conforme tabela do anexo III. Parágrafo único. No caso de não ser contemplada alguma substância ativa ou associação na tabela do anexo III, a propaganda ou publicidade deve veicular a seguinte advertência: '(nome comercial do medicamento ou, no caso dos medicamentos genéricos, a substância ativa) É UM MEDICAMENTO. SEU USO PODE TRAZER RISCOS. PROCURE O MÉDICO E O FARMACÊUTICO. LEIA A BULA.

Art. 24 A advertência a que se refere o artigo 23 deve ser contextualizada na peça publicitária, de maneira que seja pronunciada pelo personagem principal, quando veiculada na televisão; proferida pelo mesmo locutor, quando veiculada em rádio; e, quando impressa, deve causar o mesmo impacto visual que as demais informações presentes na peça publicitária, apresentando-se com, no mínimo, 35\% do tamanho da maior fonte utilizada.

I - A locução das advertências de que trata o caput deste artigo deve ser cadenciada, pausada e perfeitamente audível. (...).

Neste ponto, vem a lume o trabalho de Vívian Arraes (2010, p. 119), que estuda regras de publicidade de medicamentos em comerciais de televisão, quando faz menção a uma situação específica relativa às cláusulas de advertência: 
"Quanto ao cumprimento da legislação, analisamos que o texto com informações sobre o medicamento, como contra-indicação, composição e número de registro do medicamento, é impossível à leitura, ferindo o art. 6oa RDC 96/08. A advertência do inciso VII do art. 22 (Se persistirem os sintomas, o médico deverá ser consultado) está presente na peça, tanto escrita como locucionada. Entretanto, a indicação do art. 23 (É um medicamento, seu uso pode trazer riscos...), não é locucionada e não aparece por tempo suficiente à leitura total, o que fere mais uma vez o art. $6^{\circ}$.

É importante perceber que as informações importantes sobre o medicamento são inseridas na peça de maneira 'falsa', pois não permitem que o consumidor realmente tome conhecimento delas. Elas constam na peça somente para evitar as sanções da Lei, e o desrespeito é cometido de forma bastante sutil. Isso reflete '(...) o quanto as informações sobre riscos, efeitos adversos, advertências e precauções são negadas ao consumidor' (NASCIMENTO, 2007, p. 207).”

O que a autora chama de informações inseridas de maneira "falsa", revela o cumprimento meramente formal da norma. Ou seja, há disposições sendo cumpridas formalmente mas que no contexto não atingem a finalidade que sustenta a regra; essa finalidade é a informação ao consumidor.

Analogamente, é o caso da propaganda eleitoral, cuja finalidade é proporcionar ao eleitor e ao candidato a oportunidade de, respectivamente, receber e transmitir informação, como um direito daquele e um direito-dever desse.

Mas não se pode transmitir informação alguma de modo razoável sem meio para tal, sem um mínimo de tempo razoável, sob pena de cumprir apenas formalmente o requisito de espaço de propaganda.

\subsection{O critério do tempo mínimo}

O tempo mínimo para a veiculação de uma mensagem não se limita a uma questão formal mas, muito antes, reflete um componente essencial para a própria mensagem, que é sua viabilidade. Não é possível considerar que qualquer mensagem possa ser transmitida em qualquer espaço de tempo. Em um segundo não seria razoavelmente possível que uma mensagem pudesse ser transmitida durante a propaganda eleitoral. Pois bem. E em dois segundos? Em três? Qual seria esse tempo mínimo? Obviamente não há uma resposta exata, mas há indicativos importantes. 
De início é preciso compreender que a finalidade do espaço é a propaganda eleitoral, e nesse caso, a mensagem referida será aquela destinada a abordar o candidato e suas ideias. Há liberdade para outras espécies, para variações e até para abordagens diversas, que serão admitidas igualmente pelo sistema eleitoral, mas para fins de estabelecimento de um parâmetro há de ser levada em conta a finalidade mencionada.

O primeiro parâmetro a se fixar, portanto, é o tipo de mensagem que se destinará a apresentar pessoa ou ideia. $\mathrm{O}$ segundo parâmetro diz respeito aos signos utilizados numa mensagem e, partindo do padrão empregado pelo homem médio, a adoção de palavras, de modo que interessa saber a quantidade dessas que se pode pronunciar em dado espaço de tempo.

O critério, portanto, será a quantidade de palavras por determinado lapso, o que resulta numa medida de velocidade. Por evidente que não se trata de mera contagem de palavras, porque se permitiria, numa velocidade extrema, um excesso que estaria a comprometer a qualidade da compreensão, como no distúrbio da taquifemia ou numa locução de corrida de cavalos. A pronunciação há de ser de tal ordem que permita a fácil compreensão.

Apenas como uma referência, lição de Charles Brown (1961, p. 88):

Embora não possamos afirmar que exista uma velocidade ideal de falar, pois esta varia de acordo com o temperamento do orador e as emoções que o discurso acarreta, o fato de que os estudantes tantas vezes se criticam uns aos outros, neste ponto, indica que os ouvintes se ressentem com a pressa. Julgam-se roubados de certa riqueza de comunicação de que poderiam gozar se a celeridade fosse menor.

Socorramo-nos, pois, da fonoaudiologia. Estudando a questão da velocidade da fala, Letícia Celeste (2006) aponta características desta, associadas às pausas, que dizem respeito à organização temporal:

Uma das principais funções da prosódia é a expressão de atitudes. Através da variação de parâmetros como entonação, intensidade e organização temporal (velocidade de fala e pausas) o ser humano é capaz de transmitir atitudes diferenciadas, como a certeza e a dúvida. (...) A velocidade de fala pode ser relacionada com o ritmo que cada indivíduo imprime a seu discurso, adequando-se ao contexto e a própria situação na qual ele se encontra (BEHLAU e PONTES, 1995). Dessa forma, unem-se dois parâmetros relevantes para a velocidade 
de fala: aspectos individuais e o ambiente. Estudos sobre a velocidade de fala considerando esses dois fatores foram desenvolvidos no estudo de falantes nativos em diferentes idades (FOLHA e FELICIO, 2009; MARTINS e ANDRADE, 2008), distúrbios de fala e linguagem (WERTZNER e SILVA, 2009; AZEVEDO e CARDOSO, 2009) e expressividade. Dentro desta última, podemos considerar os atos de fala, as emoções e as atitudes. Estudos sobre a organização temporal no comando militar verificaram que tanto a velocidade de fala quanto a localização das pausas apresentaram tendências relevantes neste tipo de discurso (CELESTE et. al., 2006; COELHO, 2007). Alguns autores apontam que a variação da velocidade de fala pode ser utilizada na expressão de emoções, com menor velocidade de fala na expressão de carinho e maior na expressão de raiva (BARBOSA et. al., 2009).

Esses indicadores demonstram que a velocidade da fala deve ser levada em conta para a qualidade da comunicação. Ou seja, para uma comunicação eficaz, seja por estilo ou estratégia, com inclusão de pausas ou não, a fala pode ser desacelerada, o que pode reduzir a média de velocidade. É preciso, pois, considerar que a mensagem precisa de tempo, e esse tempo pode vir a ser maior conforme a característica do emissor ou da própria emissão.

Num estudo recente, Luanna Costa e outros (2015) dissertam sobre a velocidade da fala como indicativo de aferição da comunicação:

Ressalta-se, portanto a importância de se estudar a melhor metodologia para avaliação da velocidade de fala, uma vez que a mesma pode ser utilizada não só para avaliar os distúrbios de fluência como a efetividade comunicativa de forma mais ampla.

Os pesquisadores encontraram (loc. cit.) uma taxa média de elocução de 76 palavras por minuto num padrão comunicativo para a faixa etária de 40 a 49 anos. Essa é uma referência razoável para que se possa avaliar a capacidade de comunicação de uma mensagem em relação ao tempo disponível.

É o ponto nevrálgico do tópico, uma das motivações para determinar a viabilidade ou inviabilidade de uma determinada correlação de tempo para a transmissão de uma mensagem qualquer. A média de 76 palavras por minuto pode vir a ser ainda menor, como visto antes, de acordo com as peculiaridades do comunicador ou da mensagem. 
É possível afirmar, portanto, a necessidade de fixar um tempo mínimo e que esse deverá tomar como critério pelo menos a velocidade da fala e a quantidade de palavras compreensíveis. Isso nos leva a concluir, com segurança, que em curtos espaços de tempo não há condições humanas para a razoável transmissão e intelecção de uma mensagem completa, no âmbito do processo eleitoral, em que o conteúdo é denso por natureza e exige pelo menos uma abordagem sobre alguém (candidato) ou sobre uma ideia (programa).

\subsection{O direito de resposta como parâmetro}

Por que adotar o parâmetro do direito de resposta?

Uma das funções do direito de resposta, ao lado da neutralização das consequências dos abusos na comunicação, segundo o ministro Celso de Mello, do STF, é "restaurar e preservar a verdade pertinente aos fatos reportados pelos meios de comunicação social” (STF, ADPF 130/DF)

Mas o decano vai além ao apontar precisamente o espírito da lei neste ponto:

Vê-se, daí, que a proteção jurídica ao direito de resposta permite, nele, identificar uma dupla vocação constitucional, pois visa a preservar tanto os direitos da personalidade quanto assegurar, a todos, o exercício do direito à informação exata e precisa. (loc. cit.)

Basta o prejuízo em face de manifestação de pensamento produzida por outrem para que o ofendido esteja habilitado a requerer o direito de resposta, ainda "diante de qualquer manifestação política - mesmo as de propaganda institucional de partidos políticos”, afirma Alberto Rollo (2004, p. 217).

O direito de resposta equivale aos embargos de declaração do mundo extraprocessual. Não tem função de revide, vingança, contra-ataque, mas de reparação de erros. Embora se aplique não apenas para a hipótese de ofensa mas também de distorção dos fatos ou informações inverídicas, em qualquer dos casos o objetivo é trazer a situação ao status quo ante. Não é uma oportunidade para o ofendido levar vantagem e sim restaurar a informação que chega ao eleitor, na medida do possível, ao ponto que era antes da ofensa. 
Daí porque é possível entender que o direito de resposta tem o molde de um espaço de informação, não de cunho processual ou como mero reparo, mas como informação mesmo, tal qual aquela propiciada no espaço da propaganda. Isso porque mesmo quando o exercício da resposta seja para reparar, ele está fazendo a função que originalmente faz a propaganda - informação - e seria desnecessária caso inexistisse a ofensa. Com esse perfil, o direito de resposta está habilitado a servir de parâmetro.

Evidentemente que se a lei dispusesse especialmente sobre a questão ou contivesse alguma outra disposição em que se pudesse extrair o parâmetro, não seria necessária a adoção do direito de resposta. Mas não havendo outra fonte, ou outro parâmetro, e estando presente a necessidade de uma interpretação que traga solução para essa questão, o mais adequado que se pode encontrar, para não haver invencionice, está no critério usado pelo legislador no direito de resposta.

E por que não, por exemplo, o tempo de propaganda por inserção, conforme o art. 51?

O tempo de propaganda por inserções, de trinta segundos, não tem a mesma finalidade do direito de resposta, nem uma identidade com a propaganda eleitoral principal, em rede. Isso porque as inserções constituem mensagens complementares à principal.

A propaganda em rede tem uma disposição concentrada, que se repete diariamente na mesma posição, uma apresentação solene - com abertura e encerramento do espaço claramente identificadas - e com tempo expressivo, muito mais amplo, o que torna esse espaço o principal momento da propaganda.

Já a propaganda em inserções é difusa por toda a programação; varia de horário a cada dia, não se repete nas mesmas posições e quantidades, e não tem uma apresentação solene, já que inexiste aviso oficial ou da emissora de que a inserção está sendo iniciada ou encerrada, além de ter dimensão temporal ínfima, podendo corresponder a um décimo do tempo de rede no caso do segundo turno.

As características citadas, certamente fazem da propaganda por inserções um espaço secundário, complementar, e como tal, sem a obrigatória condição de oferecer um lugar que ofereça aquela mesma oportunidade, aquele mesmo espaço que possa razoavelmente conter uma mensagem completa. 
As céleres peças esparramadas ao longo da programação, que podem surgir para o eleitor a qualquer momento, de inopino (embora programadas num plano de mídia pelo candidato), não serão jamais elementos preeminentes da propaganda. Logicamente, até pela disposição e pelas características, essas partículas são complementares, contingentes, adicionais.

O direito de resposta, portanto, é o único parâmetro razoável a se empregar na interpretação dessa quaestio.

Por idêntico fundamento, o tempo proporcional ao agravo é previsto na Constituição e na legislação, visando um espaço razoável para o conteúdo. Ribeiro (op. cit., p. 201), fazendo referência ao direito de resposta, justifica a regra do tempo proporcional ao agravo, garantido o piso de um minuto, "para possibilitar o devido esclarecimento, contraditório e defesa, principalmente nos casos em que a ofensa se restringe a uma ou poucas palavras." E defende, na sequência, o direito do ofendido se valer da regra de prevista no $\int 6^{\circ}$ do art. 47 da Lei das Eleições (acumulação de frações inferiores a 30 segundos) para o exercício da resposta, "para que alcance o escopo da norma legal, evitando que mensagens truncadas prejudiquem a resposta".

Esse argumento é um dos suportes do presente trabalho, na medida em que a finalidade do tempo de propaganda, assim como a do tempo de resposta, é garantir a transmissão de uma mensagem, de modo que possa ser razoavelmente compreendida.

É interessante notar que a Lei 13.188/2015, que trata do direito de resposta no âmbito do direito civil, traz uma disposição que induz à conclusão de que o instituto tem uma finalidade a ser cumprida e a inobservância de certos elementos resulta na sua ineficácia (ou, na letra da lei, inexistência). Diz a lei:

Art. $4^{\circ}(\ldots)$

\3ำ A resposta ou retificação cuja divulgação, publicação ou transmissão não obedeça ao disposto nesta Lei é considerada inexistente. (...)

Nossa compreensão é a de que não se trata de um aspecto formal, não basta oportunizar a resposta, há de ser uma oportunidade real, suficiente, minimamente razoável, sob pena de não atingir a finalidade e, portanto, não representar uma reparação, conforme o espírito da lei. Nisto se insere a questão do tempo. Uma resposta que não tenha uma dimensão razoável é uma não-resposta. 
Esta é a chave para abrir a discussão do tempo mínimo de propaganda eleitoral. Uma mensagem em condições precárias não atinge sua finalidade. Uma propaganda acondicionada em espaço temporal insuficiente é uma não propaganda. E este parâmetro do direito de resposta nos dá a saída.

\subsection{Direito de resposta}

O direito de resposta ganhou regulação própria no âmbito civil, por meio da Lei 13.188, de 11 de novembro de 2015, que manteve disposições da Lei de Imprensa, com exceção justamente do critério de tempo mínimo de um minuto.

Trata-se de uma evidente involução legislativa. E essa circunstância merece uma breve anotação. A Lei 13.188/2015 teve origem no Projeto de Lei do Senado Federal (PLS) 141/2011, de autoria do senador Roberto Requião. O texto original assim dispunha, no que interessa:

Art. $4^{\circ} \mathrm{A}$ resposta ou retificação atenderão, quanto à forma e à duração, ao seguinte: (...)

II - praticado o agravo em mídia televisiva, terá a resposta ou retificação o destaque, a publicidade, a periodicidade e a duração da matéria que a ensejou, acrescida de três minutos;

III - praticado o agravo em mídia radiofônica, terá a resposta ou retificação o destaque, a publicidade, a periodicidade e a duração da matéria que a ensejou, acrescida de dez minutos. (...)

A proposição continha uma inovação relevante, ao dispor sobre um acréscimo ao tempo da resposta - igual ao tempo da ofensa - de três minutos quando na televisão e de dez minutos para o rádio. Essa ideia, contudo, foi radicalmente abolida já na primeira emenda substitutiva, que extirpou do texto esses acréscimos. Diz o parecer da Comissão de Constituição, Justiça e Cidadania, sob a relatoria do senador Pedro Taques:

Ademais, no texto do art. $4^{\circ}$, incs. II e III, e no $\ 1^{\circ}$, com a premissa de resguardar a efetiva proporcionalidade entre a ofensa e a resposta ou retificação, própria da previsão constante no inc. $V$ do art. $5^{\circ}$ da $\mathrm{CR}$, optamos por retirar do texto os acréscimos injustificados na duração do exercício do direito em relação à duração da ofensa (inc. II e III) e substituir a palavra 'idêntico' por 'proporcional' (\$ $\left.1^{\circ}\right)$. Ponderemos que essas modificações resguardam os objetivos da norma Constitucional, impedindo excessos e eventuais arbitrariedades judiciais. 
Dali o texto seguiu para a Câmara dos Deputados (PL 6.446/2013) e manteve até o fim, nesta parte, a redação substitutiva, hoje na Lei 13.188/2015:

Art. 4ํ A resposta ou retificação atenderá, quanto à forma e à duração, ao seguinte:

I - praticado o agravo em mídia escrita ou na internet, terá a resposta ou retificação o destaque, a publicidade, a periodicidade e a dimensão da matéria que a ensejou;

II - praticado o agravo em mídia televisiva, terá a resposta ou retificação o destaque, a publicidade, a periodicidade e a duração da matéria que a ensejou;

III - praticado o agravo em mídia radiofônica, terá a resposta ou retificação o destaque, a publicidade, a periodicidade e a duração da matéria que a ensejou. (...)

Reitera-se: a Lei 13.188/2015 representou, no ponto, um recuo na escala evolutiva da legislação. A fixação de um tempo mínimo visa resguardar a finalidade da resposta, que não pode ser meramente formal mas efetivamente oferecer condições de uma restauração da informação deturpada.

Imagine-se a hipótese em que a mensagem ofensiva se limita a dizer que uma pessoa cometeu determinado crime, algo como, numa linguagem popularesca, "fulano roubou na Prefeitura". Essa afirmação pode ser dita com clareza em três segundos. Mas em três segundos nenhuma resposta será bastante clara para desfazer a mensagem original.

Por mais concisão que se busque, por maior que seja o poder de síntese ou a qualidade estilística da comunicação, não será possível se chegar a uma resposta minimamente satisfatória. É induvidoso que uma resposta, qualquer que seja, inserida num tempo ínfimo, não pode atingir o seu mister. Numa situação como a que se põe, a condição é pior do que irrazoável, é irrealizável. Se o comando constitucional manda que se garanta resposta proporcional ao agravo, como se poderia, no exemplo referido, atender à Lei Maior?

Note-se que o texto diz que a resposta deve ser "proporcional ao agravo" e não "num tempo proporcional ao tempo do agravo". Obviamente que em sede de preservação de direitos fundamentais não se está a discutir o conteúdo jurídico formal e sim real. A resposta somente será 
proporcional ao agravo se puder minimamente representar uma mensagem que cumpra seu propósito, dentro dos limites da razoabilidade.

O Código Eleitoral atual (Lei 4.737, de 15 de julho de 1965) não continha originalmente disposições acerca do direito de resposta, que acabou contemplado com a inclusão do $\int 3^{\circ}$ do art. 243, por força da Lei 4.961, de 4 de maio de 1966, assim:

Art. 243. (...)

$\int 3^{2}$ É assegurado o direito de resposta a quem fôr, injuriado difamado ou caluniado através da imprensa rádio, televisão, ou alto-falante, aplicando-se, no que couber, os artigos. 90 e 96 da Lei no 4.117, de 27 de agôsto de 1962.

O tempo mínimo do direito de resposta previsto no art. $58, \int 3^{\circ}$, da Lei 9.504/97 veio como reprodução de parte da legislação antecessora:

Art. 58. A partir da escolha de candidatos em convenção, é assegurado o direito de resposta a candidato, partido ou coligação atingidos, ainda que de forma indireta, por conceito, imagem ou afirmação caluniosa, difamatória, injuriosa ou sabidamente inverídica, difundidos por qualquer veículo de comunicação social. (...)

$\int 3^{\circ}$ Observar-se-ão, ainda, as seguintes regras no caso de pedido de resposta relativo a ofensa veiculada: (...)

III - no horário eleitoral gratuito:

a) o ofendido usará, para a resposta, tempo igual ao da ofensa, nunca inferior, porém, a um minuto;

\section{Interpretação conforme a Constituição: um minuto}

Interpretação conforme é uma técnica (CRUZ, 2016), um processo (BARROSO, 2010) ou princípio (CANOTILHO, 1998, p. 1189) para atividade hermenêutica na qual, mantendo-se o texto legal interpretado, dar um sentido que não represente violação ou incompatibilidade com a Constituição Federal. Há uma menção no art. 28 da Lei 9.868/99, que trata das ações diretas de inconstitucionalidade e declaratórias de constitucionalidade, à interpretação conforme, o que apenas vem positivar o que já ocorria na prática. 
Gabriel Pinheiro (2013, p. 7) noticia que a primeira aplicação desta técnica no STF teria se dado antes mesmo da atual Carta Magna, em 1987, em acórdão da lavra do ministro Moreira Alves na Representação 1417.

A interpretação conforme para ajustar a lei aos preceitos fundamentais políticos e à salubridade democrática não é inédita na jurisdição do STF, que na já referida ADI 5105 assim dispôs:

A postura particularista do Supremo Tribunal Federal, no exercício da judicial review, é medida que se impõe nas hipóteses de salvaguarda das condições de funcionamento das instituições democráticas, de sorte (i) a corrigir as patologias que desvirtuem o sistema representativo, máxime quando obstruam as vias de expressão e os canais de participação política, e (ii) a proteger os interesses e direitos dos grupos políticos minoritários, cujas demandas dificilmente encontram eco nas deliberações majoritárias.

Inobstante se trate de um método de interpretação da lei e, portanto, empregado na atividade jurisdicional, nada impede que se possa adotá-lo como forma de se otimizar a compreensão do tema. Para tanto, necessário considerar, diante do que foi dito até este ponto, pelo menos três premissas.

A primeira é o conjunto de princípios eleitorais (partidarismo, equilíbrio no pleito, paridade na competição e legitimidade eleitoral), e de princípios constitucionais aplicáveis ao direito eleitoral (democracia, republicanismo, igualdade, proporcionalidade e razoabilidade). É fundamental ter em mente que esses postulados formam um amálgama e aí se assenta a interpretação. Não se pode considerar cada princípio individualmente, mas no conjunto, porque é assim mesmo, sistemática e organicamente, que o direito há de ser vislumbrado. E não se diga que apenas os princípios constitucionais devem ser levados em conta para a interpretação conforme, porque os demais, ainda que no plano legal, derivam da Carta, direta ou indiretamente, ou pelo menos foram por ela recepcionados.

A segunda premissa é a de que a comunicação - e por extensão a informação que a compõe - somente pode ser considerada por inteiro quando respeitar um mínimo de condições, relativamente ao emissor, ao receptor, ao meio e à mensagem. A ausência ou deficiência relevante de algum elemento afetará o resultado a tal ponto de não representar aquilo que se considera essencial. Dentre essas condições se extrai a velocidade, o ritmo, a forma e o tempo das palavras, que são elementos indicativos da qualidade 
da comunicação. Ou seja, não se trata de apenas informar, mas informar adequadamente, o que nem sempre acontece se as condições mínimas não estiverem presentes.

A terceira premissa dessa interpretação está na escolha do parâmetro de tempo mínimo, tendo sido adotado o do direito de resposta pela identidade vocacional. Não havendo disposição legal específica, é preciso buscar nalgum ponto um critério. Estando o direito de resposta situado no âmbito do mesmo ramo (direito eleitoral) e sistema (eleitoral), e tendo finalidade voltada também para a informação, este instituto se encontra habilitado à vaga.

Com base nessas premissas é possível se chegar a uma conclusão segura e com um fundamento jurídico. O tempo mínimo de um minuto deve ser observado em respeito ao direito de acesso à informação e, por consequência, à legitimidade e à plenitude democrática do pleito.

Essa é a melhor interpretação das disposições legais relativas à distribuição do tempo de propaganda em rede no rádio e na televisão, especialmente previstas no art. 58, \3o, da Lei 9.504/97, em consonância com os ditames constitucionais vigentes.

\section{Considerações finais}

Garantir o tempo mínimo um minuto de propaganda eleitoral no rádio e na televisão tem implicações práticas. Uma delas é a possibilidade de que haja mais candidatos do que a quantidade de frações equivalentes ao tempo mínimo. A resolução desse problema pode ser diferida para outro momento, outra instância, mas também pode integrar a análise, e essa é de fato uma circunstância a se ter em conta.

Não há dúvida de que eventual decisão judicial sobre o tema possa ter um viés consequencialista. Consequencialismo (ou utilitarismo) é uma expressão filosófica que indica a consequência de um ato decisório como essencial à motivação deste. Em outras palavras, não se pode tomar uma decisão sem considerar suas consequências, com o objetivo de que a decisão seja tomada visando o melhor resultado possível. É compreensível, e é até plausível que assim seja. Afinal, há uma distância entre o mundo real e o ideal, e o pragmatismo do cotidiano social não pode ser ignorado. Sabe-se que tempo de televisão e rádio tem implicações econômicas, custos, e eventualmente, repercussão em cadeia para outras partes envolvidas. 
Mas é possível compreender também que o consequencialismo não implica renúncia a valores, e nem mesmo incompatibilidade com preceitos éticos. Claro que não. Estamos sujeitos a uma série de regras das mais variadas dimensões, mas todas lastreadas em princípios, tudo imbricado num sistema jurídico nacional que se integra a uma universalidade de valores majoritariamente compreendidos e aceitos no plano internacional.

Concordamos todos que esses princípios universais e, em decorrência, as leis e suas bases teleológicas, hão de ser observados no processo de interpretação e de decisão. Assim sendo, não se pode ignorar que além da consequência de natureza econômica há outra, de natureza político-social, de muito maior relevo, que é justamente a quebra da legitimidade do processo eleitoral. A ausência de garantia do direito à informação do eleitor, e o cerceamento do direito de expressão do candidato, para ficar apenas nesses exemplos, representam por si só uma violação grave ao conjunto principiológico que sustenta o processo eleitoral. Não há pior consequência que essa.

Não é sobre um minuto de rádio ou televisão. É sobre democracia. Um processo eleitoral limpo, verdadeiro, legítimo, não acontece sem que os fundamentos constitucionais sejam respeitados, e nesse espectro estão a liberdade de manifestação e, principalmente, o direito de receber informações. O jogo só será limpo se todos estiverem em condições de jogar.

Uma visão minimamente holística nos obriga a ver que no processo eleitoral a informação é apenas a ponta do iceberg da democracia. É preciso cuidar disto como um bem precioso. Não se pode por tudo a perder por causa de um minuto. 


\section{Referências}

ALARCON, Anderson de Oliveira. A televisão e o instituto da concessão pública. Revista Jus Navigandi, ISSN 1518-4862, Teresina, ano 10, n. 891, 11 dez. 2005. Disponível em: <https://jus.com.br/artigos/7654>. Acesso em: 20 nov. 2018.

ALCURI, Gabriela et al. O Relatório MacBride: história, importância e desafios. Simulação das Nações Unidas para Secundaristas, 2012. Disponível em: <http://sinus.org.br/2012/wp-content/uploads/05-AC.pdf>. Acesso em: 18 nov. 2018.

ALMEIDA, Candido Eduardo Mendes de. A autorregulamentação publicitária no Brasil. 2013. Disponível em: <https://www.maxwell.vrac.puc-rio.br/colecao.php?strSecao=resultado \&nrSeq=22521@1>. Acesso em: 09 nov. 2018.

ÂNGELO Castro diz que a eleição é uma fraude e não apresenta promessas específicas para SC. Jornal do Almoço, reportagem, 11 set. 2018. Disponível em: <https://g1.globo.com/sc/santa-catarina/eleicoes/2018/noticia/2018/09/11/ angelo-castro-diz-que-a-eleicao-e-uma-fraude-e-nao-apresenta-promessas-especificas-para-sc-em-entrevista-ao-jornal-do-almoco.ghtml>. Acesso em: 22 nov. 2018.

ASSOCIAÇÃO DOS PROFISSIONAIS DE PROPAGANDA - APP. Código de Ética. Disponível em: < http://appbrasil.org.br/app-brasil/servicos-e-manuais/codigo-de-etica-dos-profissionais-de-propaganda/>. Acesso em: 09 nov. 2018.

ARRAES, Vívian Larissa Alves Araújo. Publicidade de medicamentos nos comerciais de TV: ética e legislação em defesa da saúde do consumidor. Monografia. Fortaleza: UFCE, 2010. Disponível em:http://www.repositorio.ufc. br/bitstream/riufc/26718/1/2010_tcc_vlaaarraes.pdf Acesso em: 18 nov. 2018.

BARROSO, Luis Roberto. Interpretação e Aplicação da Constituição, $7^{a}$. Edição revista, S.P., Ed. Saraiva, 2010, pag. 194.

BENJAMIN, Antônio Herman de Vasconcellos e; MARQUES, Claudia Lima; BESSA, Leonardo Roscor. Manual de Direito do Consumidor. 3. ed. São Paulo: RT, 2010.

BRASIL. Senado Federal. Projeto de Lei do Senado - PLS, n. 141/2011. Parecer da Comissão de Constituição, Justiça e Cidadania. Disponível em: < https:/ / legis.senado.leg.br/sdleg-getter/documento?dm $=3477836 \&$ ts $=1540305975065 \&$ disposition=inline $>$. Acesso em: 08 nov. 2018. 
BRASIL. Supremo Tribunal Federal (STF). Arguição de Descumprimento de Preceito Fundamental - ADPF 130 Distrito Federal, Rel. Min. Carlos Ayres Brito, 30 abr. 2009. Disponível em: < http:/ / redir.stf.jus.br/paginadorpub/paginador.jsp?docTP=AC\&docID=605411 >. Acesso em: 08 nov. 2018.

BRASIL. Tribunal Regional Eleitoral da Bahia (TER/BA). Recurso Extraordinário - RE 2429, Rel. Juiz Harrison Targino, j. 12.12.2002.

BRASIL. Tribunal Superior Eleitoral. Recurso Especial Eleitoral - REespe n. 16183/MG, Rel. Min. José Eduardo Rangel de Alckmin, DJe de 17 fev. 2000.

BRASIL. Tribunal Superior Eleitoral (TSE). Recurso Ordinário - RO 537003.2014.6.13.0000/MG. Rel. Min. Rosa Weber, j. 30 ago. 2018. Disponível em: <http://inter03.tse.jus.br/sadpPush/ExibirDadosProcessoJurisprudencia.do?nproc $=537003 \&$ sgcla $=$ RO\&comboTribunal $=$ tse $\&$ dataDeci sao $=21 / 08 / 2018>$. Acesso em: 09 nov. 2018.

BROWN, Charles T. Introdução à Eloquência. Rio de Janeiro: Fundo de Cultura, 1961.

CÂNDIDO, José Joel. Direito eleitoral brasileiro. 11. ed. São Paulo: Edipro, 2004.

CANOTILHO, José Joaquim Gomes. Direito constitucional e teoria da Constituição. 3. Ed. Coimbra: Almedina, 1998.

CASTRO, José de Almeida. História do rádio no Brasil. Artigo disponível em: $<$ https://www.abert.org.br/web/index.php/quemsomos/historia-do-radio-no-brasil>. Acesso em: 08 nov. 2018.

CELESTE, Letícia Correa. A variação da velocidade da fala como estratégia comunicativa na expressão de atitudes. Conferência. Congresso Ibero-Americano de Fonoaudiologia. Salvador, 2009. Disponível em: <https://www.researchgate.net/publication/263006865_A_variacao_da_velocidade_de_fala_como_ estrategia_comunicativa_na_expressao_de_atitudes>. Acesso em: 18 nov. 2018.

CONEGLIAN, Olivar. Propaganda eleitoral. 11ª ed. Curitiba: Juruá, 2012.

COSTA, Luanna Maria Oliveira; MARTINS-REIS, Vanessa de Oliveira; CELESTE, Letícia Correa. Metodologias de análise da velocidade de fala: um estudo piloto. Departamento de Fonoaudiologia. Faculdade de Medicina. UFMG. Belo Horizonte, 2015. Disponível em: < http://www.scielo.br/pdf/ codas/v28n1/2317-1782-codas-28-01-00041.pdf>. Acesso em: 18 nov. 2018. 
CRUZ, Gabriel Dias Marques da. STF, interpretação conforme a constituição e reserva de plenário. Revista Eletrônica de Direito do Estado. Ano 2016, n. 224, 1․08.2016. Disponível em http:/www.direitodoestado.com.br/colunistas/ gabriel-dias-marques-da-cruz/stf-interpretacao -conforme-a-constituicao-e-reserva-de-plenario. Acesso em 20 nov 2018.

DALLARI, Dalmo de Abreu. Elementos de teoria geral do Estado. 17. ed. São Paulo: Saraiva, 1993.

DEFLEUR, Melvin L. Teorias da comunicação de massa. 5. ed. Rio de Janeiro: Jorge Zahar, 1993.

FERREIRA, Aurélio Buarque de Holanda. Novo Dicionário da Língua Portuguesa. 2. ed. Rio de Janeiro: Nova Fronteira, 1986.

GOMES, José Jairo. Direito eleitoral. 12. ed. São Paulo: Atlas, 2016.

GOMES, Neusa Demartini; CORRADI, Analaura; CURY, Luiz Fernando. A dialética conceitual da publicidade e da propaganda. 1997. Disponível em: <http://www.eca.usp.br/associa/alaic/ Livro\%20GTP/dialetica.htm>. Acesso em: 18 nov. 2018.

GONÇALVES, Bruno Lupino. Marcos regulatórios e democratização da mídia: o direito de antena. Tese. Doutorado em Direito. São Paulo: USP, 2006. Apud NEVES FILHO, Carlos. Propaganda eleitoral e o princípio da liberdade da propaganda política. Belo Horizonte: Fórum, 2012.

GONÇALVES, Guilherme de Salles. A liberdade de exercício da propaganda eleitoral e o dever de respeito às posturas municipais. In: GONÇALVES, Guilherme de Salles; PEREIRA, Luiz Fernando Casagrande; STRAPAZZON, Carlos Luiz (Coord.). Direito eleitoral contemporâneo. Belo Horizonte: Fórum, 2008.

HELLER, Hermann. Teoria del Estado. Cidade do México: Fondo de Cultura Económica, 1947. Apud DALLARI, Dalmo de Abreu. Elementos de teoria geral do Estado. 17. ed. São Paulo: Saraiva, 1993.

JOBIM, Nelson. Legislação eleitoral no Brasil. Brasilia: Senado Federal, 1996. LEIFERT, Gilberto. Entrevista. CONAR, 2002. Disponível em: < http://www. conar.org.br. Acesso em: 18 nov. 2018.

LOPES, Cristiano Aguiar. Regulação da radiodifusão educativa. Estudo. Brasília: Câmara dos Deputados, 2011. 
MACEDO, Roberto Gondo. A propaganda política no ABC Paulista: regionalidade e imagem pública no jornal Diário do Grande ABC. 2008. Disponível em: < http://www.ufrgs.br/alcar/encontros-nacionais-1/encontros-nacionais/6o-encontro-2008-1/A\%20PROPAGANDA \%20POLITICA $\% 20 \mathrm{NO} \% 20$ ABC\%20PAULISTA.pdf>. Acesso em: 09 nov. 2018.

MALUF, Sahid. Direito constitucional. 16. ed. São Paulo: Sugestões Literárias, 1984.

MELLO, Celso Antônio Bandeira de. Revista trimestral de Direito Público. V. 15. São Paulo: Malheiros, 1996.

MELO, José Marques de. Comunicação: direito à informação. São Paulo: Papirus, 1986.

MENEGUEL, Yvonete Pedra; OLIVEIRA, Oseias de. O rádio no Brasil: do surgimento à década de 1940 e a primeira emissora de rádio em Guarapuava. Disponível em: < http://www.diaadiaeducacao.pr.gov.br/portals/pde/arquivos/713-4.pdf>. Acesso em: 08 nov. 2018.

MEYNAUD, Jean. A ciência política. Rio de Janeiro: FGV, 1960.

NEVES FILHO, Carlos. Propaganda eleitoral e o princípio da liberdade da propaganda política. Belo Horizonte: Fórum, 2012.

ORLANDI, Eni Puccinelli. A linguagem e seu funcionamento: as formas do discurso. 4. ed. São Paulo: Pontes, 1996.

PINHEIRO, Gabriel Calil. Os limites à interpretação conforme a constituição na argumentação do Supremo Tribunal Federal. Monografia. Sociedade Brasileira de Direito Público, São Paulo, 2013. Disponível em: < http://www. sbdp.org.br/wp/wp-content/uploads/2018/04/235_Gabriel-Calil-Pinheiro. pdf>. Acesso em: 21 nov. 2018.

PINTO, Djalma. Direito eleitoral: improbidade administrativa e responsabilidade fiscal. 4. ed. São Paulo: Atlas, 2008.

QUEIROZ, Otávio Augusto Pereira de. Dicionário Latim-Português. 6. ed. São Paulo: Lep, 1959.

RAMAYANA, Marcos. Direito eleitoral. 8. ed. Niterói: Impetus, 2008.

RAMOS, Wolney. Propaganda Política. São Paulo: Companhia das Publicações, 2005. 
RIBEIRO, Renato Ventura. Propaganda eleitoral gratuita no rádio e na televisão e direito de resposta. In: GONÇALVES, Guilherme de Salles; PEREIRA, Luiz Fernando Casagrande; STRAPAZZON, Carlos Luiz (Coord.). Direito eleitoral contemporâneo. Belo Horizonte: Fórum, 2008.

RODRIGUES JÚNIOR, Otavio Luiz. O regime jurídico-constitucional da radiodifusão e das telecomunicações no Brasil em face do conceito de atividades audiovisuais. Revista Brasília, n. 170, abr./jun. 2006.

ROLLO, Alberto. Propaganda eleitoral: teoria e prática. 2. ed. São Paulo: RT, 2004.

ROSENZWEIG, Patrícia Quitero. História da propaganda brasileira. 2014. Disponível em: <https://pt.slideshare.net/PATRICIAQUITERO1/aula-historia-da-propaganda-brasileira>. Acesso em: 18 nov. 2018.

SANTOS, Ébida Rosa dos. A propaganda eleitoral no rádio: aspectos históricos e legais. Disponível em: <http://alcarsul2014.sites.ufsc.br/wp-content/uploads/2014/10/GT_HIST\%C3\%93RIA_DA_MIDIA_SONORA_EBIDA_ ROSA_DOS_SANTOS.pdf>. Acesso em: 08 nov. 2018.

SCORSIM, Ericson Meister. Serviço público de televisão por radiodifusão. Migalhas. 2009. Disponível em: <https://www.migalhas.com.br/dePeso/16,MI84817,101048-Servico+publico + de+televisao+por+radiodifusao $>$. Acesso em: 19 nov. 2018.

SERRANO, Daniel Portillo. Qual é a diferença entre publicidade e propaganda? Portal do Marketing. 2013. Disponível em: $<$ http://www.portaldomarketing.com.br/Artigos3/Qual_e_a_diferenca_entre_Publicidade_e_Propaganda. htm>. Acesso em: 18 nov. 2018.

SILVA, José Afonso da. Comentário contextual à Constituição. 3. ed. São Paulo: Malheiros, 2007.

SILVA, José Afonso da. Curso de Direito Constitucional Positivo. 19. ed. São Paulo: Malheiros, 2001.

SILVA, Henrique Neves da. Como o eleitor saberá quem são os candidatos e o que dizem? Disponível em: <https://www.jota.info/opiniao-e-analise/ colunas/e-leitor/como-o-eleitor-sabera-quem-sao-os-candidatos-e-o-que-dizem-05072018>. Acesso em: 04 nov. 2018. 
SILVA, Milton Wagner da. Isso é uma calúnia! A regulamentação do direito de resposta e o possível uso abusivo por agentes políticos. Monografia. UFPR, 2016. Disponível em: < https://acervodigital.ufpr.br/bitstream/handle/1884/46107/69.pdf?sequence=1>. Acesso em: 09 nov. 2018.

TOMÁS, Luís. Propaganda Fide. Revista Fátima Missionária. Ed. LIII, jun. 2007.

UNESCO. Um Mundo e Muitas Vozes: comunicação e informação na nossa época. Rio de Janeiro: Editora da Fundação Getúlio Vargas, 1983. Título original: Many Voices One World, Towards a new more just and more efficient world information and communication order. Paris. Unesco, 1980. Disponível em: $<$ http://unesdoc.unesco.org/images/0004/000400/040066eb.pdf>. Acesso em: 18 nov. 2018.

ZYMAN, Sergio. A propaganda que funciona: como obter resultados com estratégias eficazes. 2. ed. Rio de Janeiro: Elsevier, 2003.

Nelson Zunino Neto - Advogado em São João Batista SC. Graduado em Direito (FURB) e Pós-graduado em Direito Eleitoral (IDDE). Concluiu o curso de preparação da Escola Superior da Magistratura de Santa Catarina (ESMESC). Atuou como convidado em comissões parlamentares de inquérito municipais. Palestrante sobre reforma política, legislação eleitoral e improbidade administrativa. $\mathrm{Na} \mathrm{OAB} / \mathrm{SC}$ participou, dentre outras, da Comissão de Moralidade Pública, além de ter sido vice-presidente da Comissão de Direito Eleitoral. É membro da Academia Catarinense de Direito Eleitoral (ACADE) e do Instituto dos Advogados de Santa Catarina (IASC). Autor da obra Tempo Minimo de Propaganda Eleitoral em Rádio e TV: por um jogo justo (Habitus, 2020). 